\title{
A review of the various treatments of oil-based drilling fluids filter cakes
}

\author{
Osama Siddig $^{1} \cdot$ Ahmed Abdulhamid Mahmoud $^{1} \cdot$ Salaheldin Elkatatny ${ }^{1}$ (i)
}

Received: 9 November 2021 / Accepted: 14 December 2021 / Published online: 22 December 2021

(c) The Author(s) 2021

\begin{abstract}
Treatment of the filter cake layer after drilling is essential for better cement integrity and to retain the original reservoir permeability. Compared to water-based filter cake, oil-based mud filter cake removal is more sophisticated as oil encloses the filter cake's particles. Therefore, oil-based mud clean-up requires wettability alteration additives (mutual solvents and/ or surfactants) for permitting acid/filter cake reaction. With an appropriate acid, microemulsions were reported to be very efficient in cleaning oil-based filter cakes, due to their low interfacial tension and high acid solubility. The objective of this paper is to provide an overview of the different techniques and treatment solutions utilized in oil-based filter cake clean-up. Furthermore, a synopsis of the various treatments for drilling fluids densified with different weighting materials is presented. Subsequently, the research limitations and opportunities have been highlighted for future work. In the light of the review that has been presented in this paper, it's recommended to conduct further investigation on some areas related to filter cake removal. The removal of filter cake formed from weighting materials other than barite, calcium carbonate, ilmenite, and manganese tetroxide needs to be investigated thoroughly. Additionally, the overall efficiency of oil-based mud removal needs to be studied under wide ranges of temperature, salinity, and $\mathrm{pH}$. The utilization of surfactant-free microemulsions in filter cake treatment could also be investigated.
\end{abstract}

Keywords Filter cake $\cdot$ Filter cake removal $\cdot$ Oil-based drilling fluid $\cdot$ Weighting materials

\section{Introduction}

Drilling fluids are designed to facilitate the drilling operation by performing different functions such as downhole tools lubrication, rock cuttings suspension, and transportation to the surface (Fink, 2012; Gordon et al., 2008). The drilling fluids should also provide an adequate hydrostatic pressure which must be greater than the formation pressure to provide an overbalance, which is required to avoid flow from the formation into the wellbore and to keep the wells under control. Nonetheless, this excess pressure means some of the drilling fluid will invade the penetrated formation and may

Salaheldin Elkatatny

elkatatny@kfupm.edu.sa

Osama Siddig

g201105870@kfupm.edu.sa

Ahmed Abdulhamid Mahmoud

ahmed.mahmoud@kfupm.edu.sa

1 Department of Petroleum Engineering, King Fahd University of Petroleum \& Minerals, Dhahran 31261, Saudi Arabia cause formation damage, reduction in the permeability, and consequently additional cost (Iscan et al., 2007; Zhang et al., 2020). This drilling fluid invasion affects rock mechanical properties as well (Karakul, 2018).

Deposition of the solid particles from the drilling fluid onto the face of the permeable rock results in a thin layer with a permeability of less than $0.01 \mathrm{md}$ known as a filter cake (FC) as shown in Fig. 1 (Civan, 1994; Hanssen et al., 1999). The mud invasion into the drilled formation, and hence, the formation damage is diminished by the filter cake formation (Argillier et al., 1999). In this way, the filter cake formation and its characteristics are considered as principal features of any drilling fluid (Bourgoyne, 1986; Hossain and Al-Majed, 2015; Rabia, 2001).

In addition to rock pores plugging, external filter cake can plug the completion screens and gravel pack, and subsequently, the productivity/injectivity of the wells will reduce significantly; hence, it requires to be treated efficiently (Davison et al., 2001; Jiao and Sharma, 1992; Quintero et al., 2005). These drilling-related damages are more severe in horizontal wells due to longer exposure to the drilling fluids 
Fig. 1 Formation of the filter cake (Kabir and Gamwo, 2011)

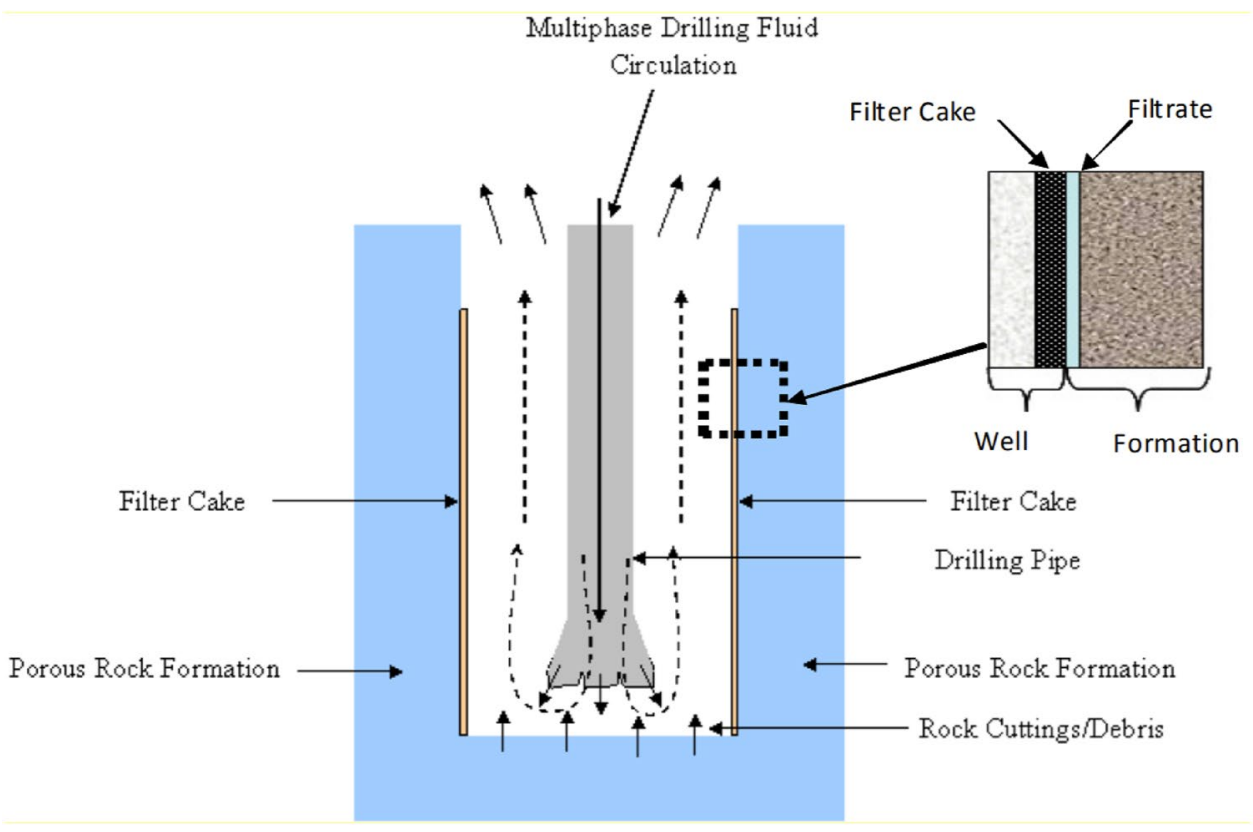

compared to vertical wells (Frick and Economides, 1993; Thomas and Sharma, 1998). The significance of formation damage varies depending on the drilling fluid properties, reservoir characteristics, and pressure (Brege et al., 2012). Recent researches showed that the utilization of nanomaterial enhanced the filtration properties of the drilling fluids (Ikram et al., 2020; 2021).

Even though the filter cake formation is very important during the drilling process to minimize the drilling fluid invasion into the drilled formation, however, efficient removal of the filter cake layer after the drilling process is a must to ensure better cementing integrity and to eliminate restriction on well productivity or injectivity (Davidson et al., 2012; Fink, 2012; Huang et al., 2019; Zain and Sharma, 1999). For efficient cementation, the face of the rock should receive the cement to form a strong bond, and this could be restricted if the filter cake is not efficiently removed (Wang et al. 2016).

In our recent publication, Siddig et al. (2020a), a comparison of the different approaches for the treatment of water-based filter cakes is reported. The objective of this paper is to report and summarize the different approaches for the removal of the filter cakes formed by oil-based drilling fluids. The diverse chemical treatments available for the removal of filter cakes containing various weighting materials are also presented in this manuscript. In the light of the review covered, future research opportunities have been highlighted.

\section{Filter cake characterization}

Different techniques have been employed to examine and characterize the filter cake formed on filter paper, ceramic disc, or core sample (see Fig. 2). These methods incorporating the scanning electron microscope (SEM), computer tomography (CT) scan, nuclear magnetic resonance (NMR), and X-ray fluorescence (XRF). The thinner, less permeable, faster to form, and easier to remove is considered to be a better filter cake (Mahmoud and Elkatatny, 2017).

Filter cake properties such as permeability, porosity, toughness, thickness, structure, particle size distribution are the key elements that influence the fluid invasion into the drilled formations, and therefore, they affect the formation productivity (Ba geri et al., 2013a; $\mathrm{Li}$ and $\mathrm{He}, 2015$ ). These properties are affected by various factors such as the type of weighting material and polymers contained in the drilling fluid, in addition to the clay content, salinity, and sand content of the filter cake layer (Ba geri et al., 2019a, 2015; Yao et al., 2014). Furthermore, previous studies showed that utilization of nanomaterials in drilling fluids improved the filter cake characteristics and resulted in thinner and more compacted filter cake layers (Boyou et al., 2019; Rafati et al., 2018; Sharma et al., 2012; Smith et al., 2018).

Several studies showed that the weighting materials are the dominant component of the filter cake and they 
Fig. 2 Filter cake formed on $\mathbf{a}$ filter paper, $\mathbf{b}$ ceramic disc and c core sample

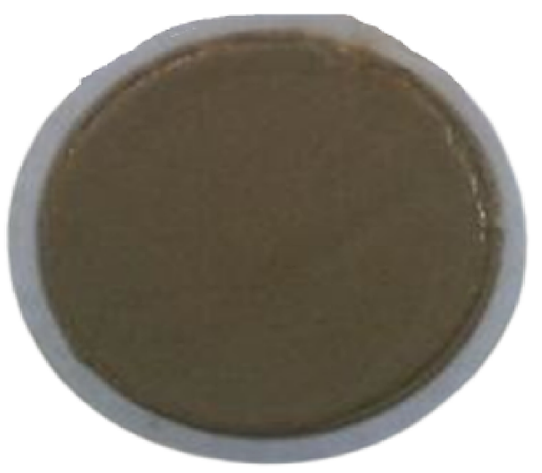

(a)

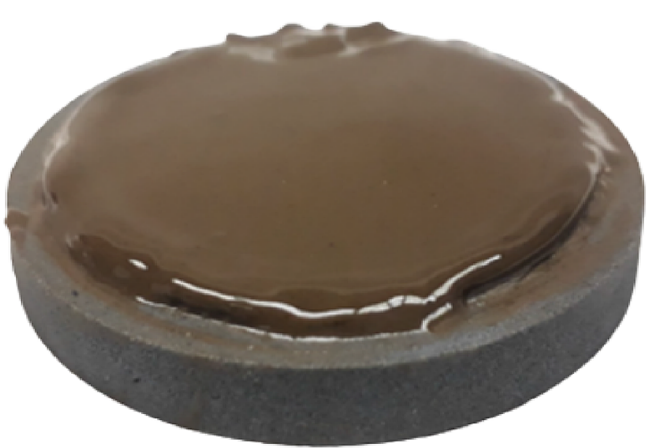

(b)

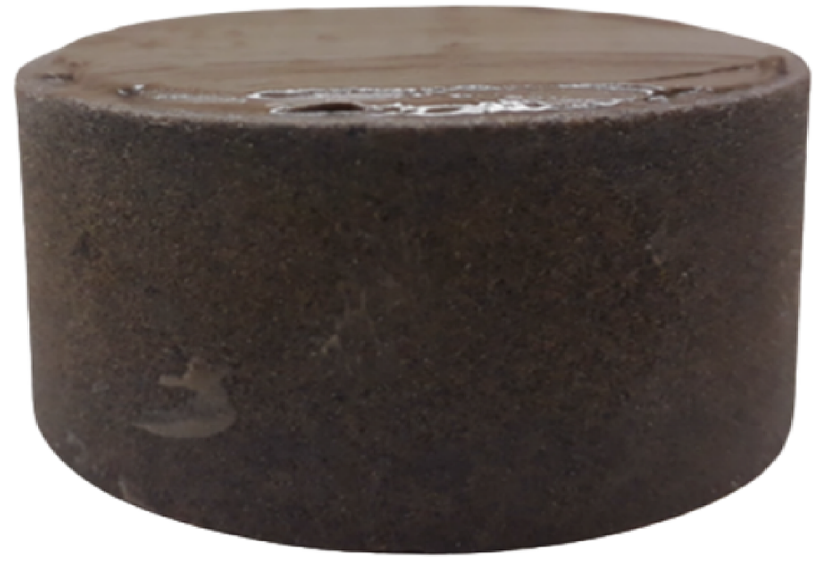

(c)

compose up to $80 \%$ of the FC layer by weight (Ba geri et al., 2017a; 2015; 2013b). CT scans showed that the FC consists of multiple layers with varying properties, the layer next to the formation surface (the inner layer) mainly comprises the weighting material while the farther layer (the outer layer) contains the polymeric additives as illustrated in Fig. 3 (Elkatatny et al., 2012a; 2011; Elkatatny et al., 2013a; Elkatatny and Nasr-El-Din, 2012a). The formation of more complex and heterogeneous layers is also expected in case of long exposure to the drilling fluids as in the extended reach wells (Hamzaoui et al., 2018). This heterogeneity significantly affects not only the filter cake filtration performance but also the effectiveness of

Fig. 3 CT scan shows filter cake that consists of two layers (Elkatatny et al., 2011) its removal process (Burnett, 1995; Caenn et al., 2017; Chellappah et al., 2010).

\section{Solvents of different weighting materials}

Weighting materials are used in the drilling fluids to increase their weight and, hence, maintain sufficient overbalanced hydrostatic pressure required throughout the drilling operation to control the well. The weighting material should render the drilling fluid with the required density while maintaining good rheology and low solids sagging tendency (Mohamed et al., 2019a; Zamora and Bell, 2004). As affirmed in the previous section, the weighting material

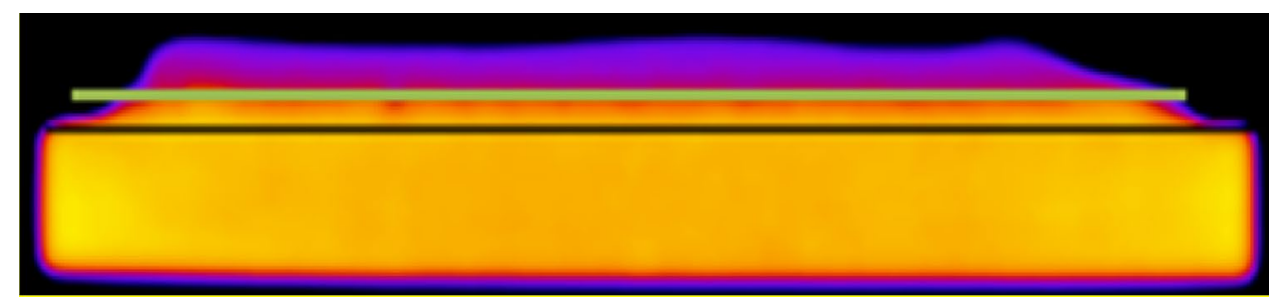


and polymeric additive are the main components of the filter cake; therefore, finding an efficient polymer breaker and a solvent for the weighting material plays a vital role in the success of the filter cake cleanup process.

Enzymes and oxidizers are used as polymer breakers (Imqam et al., 2014). Ammonium persulfate and sodium persulfate are common oxidizers used in the oil industry (Sarwar et al., 2011). On the other hand, several solvents are used for dissolving the weighting material dominant layer of the filter cake. In this section, the various acid solvents that are available for each weighting agent are presented.

\section{Barite}

Barite $\left(\mathrm{BaSO}_{4}\right)$ is the most regularly used weighting material since the 1930s (Pehrson and Keiser, 1945). However, it has some shortcomings such as low acid solubility (AlBagoury and Steele, 2012), formation damage (Al-Bagoury, 2014; Guo et al., 2012), sagging issues, high plastic viscosity (Aldea et al., 2001; Mohamed et al., 2019a; Almutawa et al., 2021), and inability to be utilized in formate brines (Howard, 1995). In expansion to that, barite is not soluble in organic acids or hydrochloric acid $(\mathrm{HCl})$, and this makes barite filter cake removal a sophisticated and expensive process (Bern et al., 2010).

Lakatos et al. (2002) investigated the use of different chelating agents to dissolve barite and concluded that ethylenediaminetetraacetic acid (EDTA) and diethylenetriamine pentaacetic acid (DTPA) are preferred when both technical and economical perspectives are taken into consideration.

To enhance the barite solubility in chelating agents, Ba geri et al. (2017b) added catalysts (converting agents) to a solution that consists of chelating agents (EDTA or $\mathrm{N}$-hydroxyethylenediaminetriacetic acid (HEDTA)) at a $\mathrm{pH}$ of greater than 12.0. Ba geri et al. (2017a) studied the performance of three different converting agents namely potassium formate, potassium chloride, and potassium carbonate when mixed with a treatment solution of potassium-based DTPA chelating agent. They reported that the addition of the converting agent improved barite solubility from 67 to $95 \%$, and out of the three catalysts, potassium carbonate gave the most noteworthy solubility enhancement.

Further studies used a high $\mathrm{pH}$ solution of potassium carbonate $\left(\mathrm{K}_{2} \mathrm{CO}_{3}\right)$ with potassium hydroxide $(\mathrm{KOH})$ to convert the barite to barium carbonate which is easier to dissolve. Then, treatment solution of $\mathrm{HCl}$ was used to dissolve the originally formed barium carbonate (Mahmoud and Elkatatny, 2017; 2019). However, the use of $\mathrm{HCl}$ to dissolve barium carbonate is not favored because it produces harmful barium chloride. Another solution suggested by the authors is to generate the high $\mathrm{pH}$ condition using the treatment solution of the EDTA at a high $\mathrm{pH}$ of
12.0 with $\mathrm{K}_{2} \mathrm{CO}_{3}$ or $\mathrm{KOH}$ as a convertor. The use of the EDTA solution introduced another advantage over that for the $\mathrm{HCl}$ which is the ability to remove the barite filter cake in a single stage because of the compatibility of the EDTA solution and the polymer breakers. In this study, the compatible polymer breaker was potassium persulfate; however, other studies reported incompatibility between the EDTA and the polymer breakers. For instance, Ba geri et al. (2017b) tested the compatibility of EDTA with three different enzymes and found all of them incompatible.

One issue identified in using chelating agents for barite FC removal is that the resulted barite chelates may release barite into formation pores. This is due to its high affinity to other minerals, which can cause secondary damage, especially in the case of non-uniform filter cake thickness (Al Jaberi et al., 2020). Figure 4 illustrates the mechanism of the secondary damage related to barite removal operation. Ba geri et al. (2019b) used NMR and micro-CT scans before and after the filter cake treatment with a chelating agent and reported a noticeable change in pore geometry of the core samples.

\section{IImenite}

Late in the 1970s, the use of ilmenite $\left(\mathrm{FeTiO}_{3}\right)$ in drilling fluid was introduced as a low-cost weighting material contrasted with standard barite (Blomberg and Melberg, 1984; Haaland et al., 1976). It also has lower pollution problems compared to barite (Al-Bagoury, 2014; Rae et al., 2001).

The high abrasiveness of ilmenite is its main shortcoming, one solution to solve this issue is to use micronized ilmenite (Al-Bagoury and Steele, 2012; Saasen et al., 2001), which likewise improves the drilling fluid filtration properties and reduces its sagging tendency (Elkatatny, 2012). Another demerit of ilmenite is the high magnetic susceptibilities that may influence the efficiency of directional drilling equipment's operation (Tehrani et al., 2014); however, this could be depreciated by reducing the magnetite content (Xiao et al., 2015).

Ilmenite is soluble in sulphuric acid $\left(\mathrm{H}_{2} \mathrm{SO}_{4}\right)$ and $\mathrm{HCl}$ and its reaction with these acids produce titanium dioxide (van Dyk et al., 2002; Fouda et al., 2010; Al-Bagoury, 2014). The dissolution rate of the ilmenite in $\mathrm{H}_{2} \mathrm{SO}_{4}$ is highly affected by the ilmenite particle size (Han et al., 1987). Habib et al. (2006) reported that when methanol is added to $\mathrm{HCl}$, the ilmenite dissolution was increased. Elkatatny et al. (2013b) compared the solubility of ilmenite in different treatment solutions of HCl, EDTA, HEDTA and glycolic acid, and they reported that the highest ilmenite solubility was achieved with $\mathrm{HCl}$ solution, while the lowest was when glycolic acid was used. 

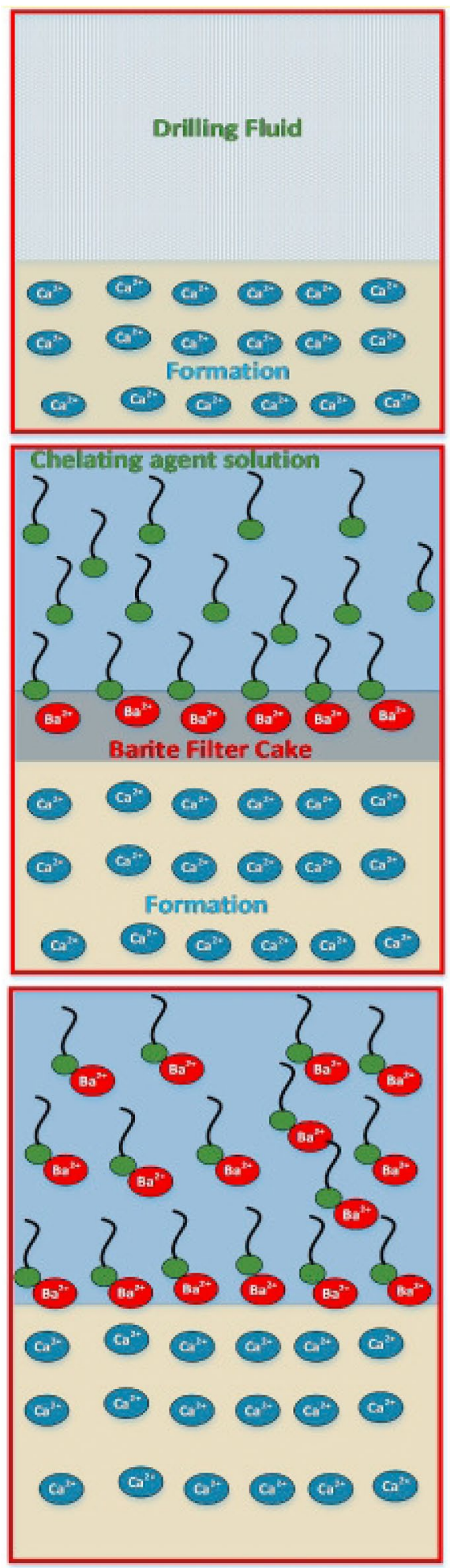

(1)

Forming Filter cake
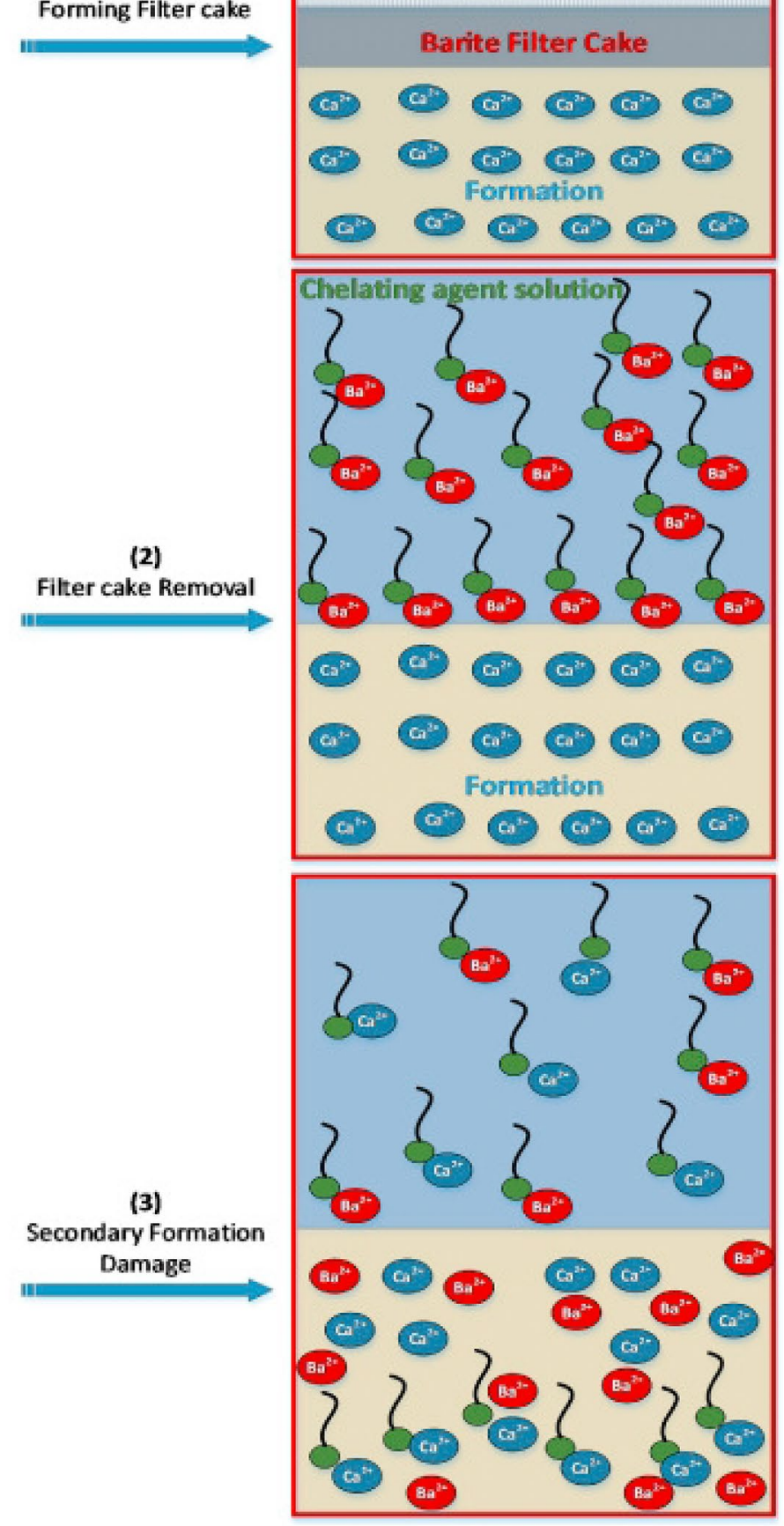

Fig. 4 Mechanism of secondary damage during barite filter cake removal (Ba geri et al., 2019b) 


\section{Calcium carbonate}

One of the low damaging weighting materials is calcium carbonate $\left(\mathrm{CaCO}_{3}\right)$ as it has high acid solubility. The fundamental impediment to the use of calcium carbonate in drilling fluid is that it has a relatively low specific gravity in contrast to the other weighting materials, which means an immense amount of $\mathrm{CaCO}_{3}$ is needed to accomplish a similar density obtained by the other weighting materials.

Several acid precursors-based treatments for calcium carbonate filter cakes removal have been presented, namely acetic acid precursor (Nasr-El-Din et al., 2005; Siddiqui et al., 2006), formic acid precursor (Al-Anzi et al., 2009; Leschi et al., 2006), and lactic acid precursor (Al-Otaibi et al., 2006; Elkatatny and Nasr-El-Din, 2012b). According to Rostami and Nasr-El-Din (2010a; 2010b), the addition of the esters to the drilling fluids' formulation doesn't significantly affect their rheological properties. Nasr-El-Din and Al Moajil (2007) examined the performance of the three acid precursors and reported that the formic acid precursor resulted in the most efficient $\mathrm{CaCO}_{3}$ removal.

In addition to the organic acids, the performance of different chelating agents in removing $\mathrm{CaCO}_{3}$ filter cake had been studied by several authors (Navarro-mascarella and Luyster, 2011; Parlar et al., 1998; Tibbles et al., 2003). Collins et al. (2011) introduced a filter cake breaker that consists of a biodegradable chelating agent to dissolve calcium carbonate filter cake. The chelating agent performance was compared with breakers that contain organic acid precursors. The chelating agent outperformed the organic acid in terms of solubility, corrosion rate and removal efficiency.

\section{Magnesium tetroxide}

Manganese tetroxide $\left(\mathrm{Mn}_{3} \mathrm{O}_{4}\right)$ is a comparatively new type of weighting agent that has a high specific gravity, low sagging tendency, and better thermal stability; however, it has higher plastic viscosity and yield point compared with $\mathrm{CaCO}_{3}$ or barite (Al-Yami and Nasr-El-Din, 2007; Svendsen et al., 1995).

Al Moajil et al. (2008) studied the $\mathrm{Mn}_{3} \mathrm{O}_{4}$ filter cake removal using different solutions of $\mathrm{HCl}$, citric, formic, lactic, and acetic acids and they found that the dissolution of $\mathrm{Mn}_{3} \mathrm{O}_{4}$ was higher in $\mathrm{HCl}$ solution. Even though the high concentration of $\mathrm{HCl}$ yields high removal efficiency, it is not recommended to use $\mathrm{HCl}$ with a concentration of higher than 4 wt.\%, since high $\mathrm{HCl}$ concentrations release toxic and corrosive chlorine gas particularly at high temperatures (Al Moajil and Nasr-El-Din, 2010). It is noteworthy that manganese citrate precipitates may occur from a reaction of $\mathrm{Mn}_{3} \mathrm{O}_{4}$ with certain solvents such as $\mathrm{N}, \mathrm{N}$-dicarboxymethyl glutamic acid tetrasodium salt (GLDA), oxalic, citric, and tartaric acids (Al Moajil and Nasr-El-Din, 2013a).
The use of glycolic acid as a treatment solution for the $\mathrm{Mn}_{3} \mathrm{O}_{4}$ FC removal was studied by Elkatatny et al. (2012b), and the results of this study showed that the effectiveness of the glycolic acid on removing the $\mathrm{Mn}_{3} \mathrm{O}_{4}$ filter cake was lower than that for $\mathrm{HCl}$. Alternatively, Elkatatny et al. (2013c) presented a treatment solution based on a combination of $\mathrm{HCl}$ and glycolic acid with high removal efficiency and safe $\mathrm{HCl}$ concentration. Similarly, Al-Moajil and NasrEl-Din (2013b) presented $\mathrm{HCl}$ and lactic acid mixture for $\mathrm{Mn}_{3} \mathrm{O}_{4}$ filter cake removal.

\section{Hematite}

Another weighting material that has been introduced as an alternative to barite is iron oxide, also called hematite (Walker, 1983). When compared to barite, hematite has almost the same specific gravity and produces a drilling fluid with similar rheological properties as barite (Tovar et al., 1999). Similar to ilmenite, abrasiveness and magnetic susceptibility are the main disadvantages of hematite (Bland et al., 2006; Tehrani et al., 2014; Walker, 1983). It also has a sagging tendency (Basfar and Elkatatny, 2020), which can be reduced by decreasing the hematite particles size; however, micronized hematite has higher fluid loss than regular size hematite (Tehrani et al., 2014). Hematite is soluble in sulfuric acid and $\mathrm{HCl}$ and has low solubility in nitric acid (Liu et al., 2003; Matsumoto et al., 1994; Sidhu et al., 1981; Weast, 1979). Even though there is a good number of publications that discuss the filter cake removal topic, the cleanup of FC formed from hematite in the drilling fluid is not available in the literature.

Table 1 summarizes the acid solvent recommended for each weighting material discussed in the previous sections. Further investigation on the removal of filter cake layers consisting of weighting materials of hematite and magnetite is recommended. To the best of our knowledge, the removal of filter cake generated by these weighting materials is not investigated thoroughly in publications.

\section{Treatment solutions performance indicators}

\section{Solubility of the weighting material}

The ability of the treatment solution to dissolve the weighting material is an essential for proper filter cake cleanup. In the solubility test, a known weight of weighting material is soaked in a specific volume of the solution for the designed duration. Afterward, the remaining weighting material will be filtrated out of the solution and its weight will be measured again and the solubility can be calculated using either Eq. 1 or Eq. 2. 
Table 1 The recommended acid solvents for different weighting materials

\begin{tabular}{|c|c|c|c|}
\hline Weighting material & Acid solvent & comments & references \\
\hline Barite & Chelating agent + catalyst & $\begin{array}{l}\text {-Different chelating agents have been } \\
\text { used (EDTA, HEDTA, DTPA, GLDA) } \\
\text {-Potassium carbonate found to be the } \\
\text { most efficient catalyst }\end{array}$ & $\begin{array}{l}\text { (Ba geri et al., 2017a, b; Mahmoud and } \\
\text { Elkatatny, 2017, 2019) }\end{array}$ \\
\hline Ilmenite & $\mathrm{HCl}$ & $\begin{array}{l}\mathrm{HCl} \text { has a higher solubility for ilmenite } \\
\text { compared to chelating agents }\end{array}$ & (Elkatatny et al., 2013b) \\
\hline Calcium carbonate & Organic acids and acid precursors & $\begin{array}{l}\text { Calcium carbonate has high acid solubil- } \\
\text { ity }\end{array}$ & $\begin{array}{l}\text { (Al-Otaibi et al., 2006; Leschi et al., 2006; } \\
\text { Nasr-El-Din et al., 2005; Nasr-El-Din } \\
\text { and Al Moajil, 2007) }\end{array}$ \\
\hline Manganese tetroxide & $\begin{array}{l}\mathrm{HCl}, \mathrm{HCl} / \mathrm{glycolic} \text { acid mixture, } \\
\text { or } \mathrm{HCl} / \text { lactic acid mixture }\end{array}$ & $\begin{array}{l}\text { Dissolution of Manganese tetroxide with } \\
\text { high } \mathrm{HCl} \text { concentration releases toxic } \\
\text { gases }\end{array}$ & $\begin{array}{l}\text { (Al Moajil et al., 2008; Al Moajil and } \\
\text { Nasr-El-Din, 2013b; Elkatatny et al., } \\
\text { 2013c) }\end{array}$ \\
\hline Hematite & $\mathrm{HCl}, \mathrm{H}_{2} \mathrm{SO}_{4}$ and nitric acid & Not studies in filter cake removal & $\begin{array}{l}\text { (Liu et al., 2003; Matsumoto et al., 1994; } \\
\text { Sidhu et al., 1981; Weast, 1979) }\end{array}$ \\
\hline
\end{tabular}

Solubility $(w t . \%)=\frac{W_{\text {before }}-W_{\text {after }}}{W_{\text {before }}} * 100 \%$

Solubility $(g / L)=\frac{W_{\text {before }}-W_{\text {after }}}{V} * 100 \%$

where $\mathrm{W}_{\text {before }}=$ weight of the weighting material before soaking in the treatment in grams, $\mathrm{W}_{\mathrm{after}}=$ weight of the weighting material after soaking in the treatment in grams, $\mathrm{V}=$ volume of treatment solution in liters.

\section{Compatibility with the Polymer Breaker}

The compatibility between the solvent and polymer breaker determines the number of stages required in the cleanup operation. If they are incompatible, the polymer breaker will be soaked first followed by the solvent in a two-stage process (see Fig. 5).

\section{Removal efficiency}

After building the filter cake on the face of core sample or ceramic disc, the HPHT cell will be used to soak the filter cake on the treatment solution for the predetermined duration and conditions. The removal efficiency can be determined from the weights before the filter cake formation, after forming the filter cake and after the removal using the Eq. 3.

Removal Efficiency $(w t . \%)=\frac{W_{2}-W_{3}}{W_{2}-W_{1}} * 100 \%$

where $\mathrm{W}_{1}=$ weight of the saturated core/disc, $\mathrm{g}, \mathrm{W}_{2}=$ weight of the filter cake containing core/disc, $\mathrm{g}, \mathrm{W}_{3}=$ core/disc weight after the removal process, $g$

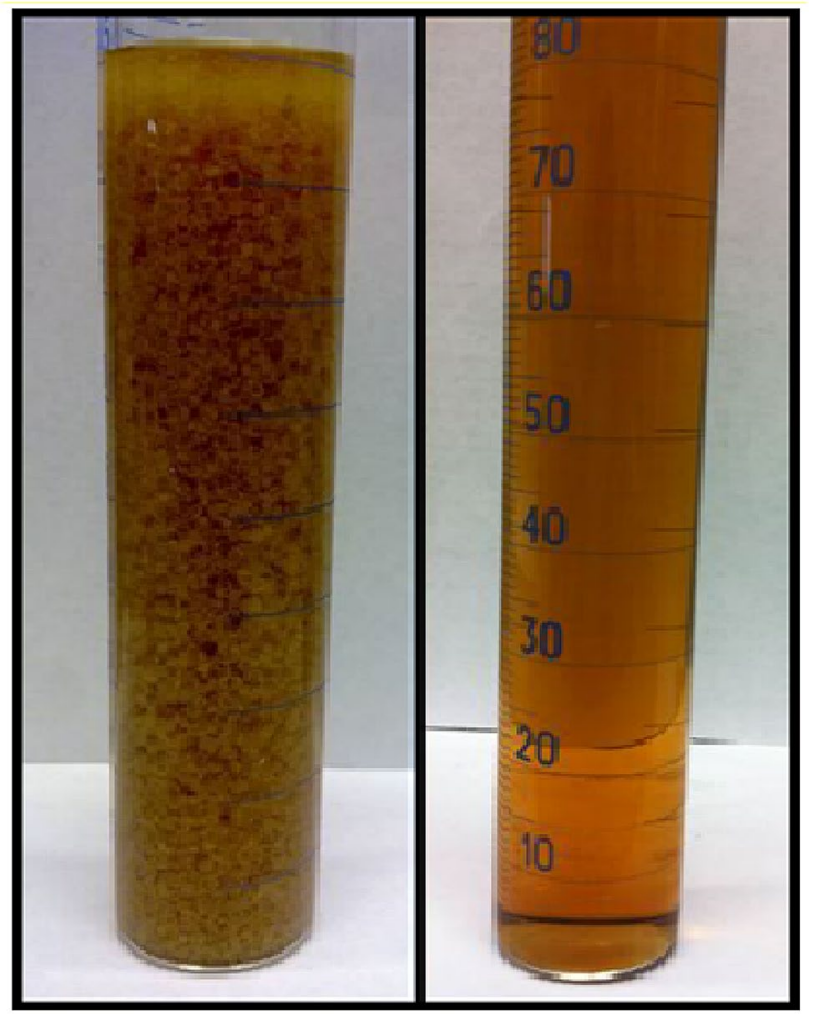

(a)

(b)

Fig. 5 Compatibility between the acid solution and polymer breaker: a not compatible b compatible (Elkatatny et al., 2012b)

\section{Retained permeability}

The removal efficiency described in the previous section measure the weight percentage of dissolved filter cake, however, that doesn't necessarily reflect the regained permeability. By measuring the permeability before forming the filter 
cake and after the treatment, the retained permeability can be calculated by Eq. 4 .

Retained Permeability $(\%)=\frac{K_{\text {after }}}{K_{\text {before }}} * 100 \%$

where $K_{\text {before }}=$ permeability of the core before forming the filter cake, $\mathrm{K}_{\mathrm{after}}=$ permeability of the core after treating the filter cake.

\section{Corrosion rate}

The corrosion rate of the treatment solution determines whether additional corrosion inhibitor will be needed or not. Corrosion is tested by hanging a corrosion coupon inside the solution at the designed temperature and duration, and then, the corrosion rate can be calculated from the weight of the coupon before and after the test as in Eq. 5 .

Corrosion rate $\left(\mathrm{lb} / \mathrm{ft}^{2}\right)=\frac{\mathrm{CW}_{\text {before }}-\mathrm{CW}_{\text {after }}}{\mathrm{SA}}$

where $\mathrm{CW}_{\text {before }}=$ weight of the coupon before the test in $\mathrm{lb}$, $\mathrm{CW}_{\mathrm{after}}=$ weight of the coupon after the test in $\mathrm{lb}, \mathrm{SA}=$ surface area of the coupon in $\mathrm{ft}^{2}$.

\section{Oil-based mud filter cake removal}

According to their main liquid continuous phase, drilling fluids are classified as water-based drilling fluids (WBDF) and oil-based drilling fluids (OBDF). In addition to the environmental concerns, OBDFs have a higher cost when compared to WBDFs, that's why WBDFs are commonly used, considering the fact that the mud cost around sixth of the overall drilling cost (Caenn and Chillingar, 1996; Jensen et al., 2004; Khodja et al., 2010). However, OBDFs have significant advantages over WBDFs such as their lower fluid loss, stable rheology, better hole cleaning ability, high thermal stability, and efficient performance when drilling through a shale formation (Ding et al., 2004; Enright et al., 1992; Patel et al., 2007; Sayindla et al., 2017). These features make the OBDFs favored in drilling through the reservoir formations (Vickers et al., 2012).

In general, OBDFs filter cake cleanup is a sophisticated, expensive, and time-consuming process (Al-Otaibi et al., 2004; Davis et al., 2004). The treatment of WBDFs filter cakes relies principally on finding an adequate polymer breaker and acid solvent for the weighting material (Siddig et al., 2020a). In the OBDFs filter cake, there is oil encompassing the filter cake formation, therefore, adding material/s to alter the wettability of the FC surface is a must, in this case, to allow for the treatment acid to react with the filter cake particles (Davidson et al., 2006; Davison et al., 2001). Mutual solvent, surfactant, or both are normally added to the OBDFs filter cake removal solution to change the filter cake wettability (Binmoqbil et al., 2009; Quintero et al., 2005). Filter cake removal should be designed cautiously acknowledging the compatibility between the different fluids involved, inappropriate cleanup process leads to pore-throat plugging and increase the formation damage which will affect the hydrocarbon production from the producing formations (Alimuddin et al., 2016; Binmoqbil et al., 2009). In the next sections, different treatments available in the literature to clean up OBDFs filter cakes are addressed.

\section{Mutual solvents and acid mixture}

Mutual solvents are chemicals soluble in water, oil, and acidic solutions and used to remove hydrocarbon deposits and to control the wettability, and subsequently, they are used for reservoir stimulation and to remove hydrocarbonbased formation damage (Hall, 1975; Hamberlin et al., 1990).

Field applications of a treatment solution for OBDF's filter cake with calcium carbonate as a weighing material were presented by Davidson et al. (2006). The treatment consists of viscosified brine, mutual solvent, and formic acid precursor (FAP). The mutual solvent used was ethylene glycol mono-butyl ether (EGMBE). They reported a return permeability of $97 \%$, and the filter cake was broken faster than a WBDF filter cake that was treated with FAP and brine without adding mutual solvents.

Ali et al. (2007) compared the performance of different $\mathrm{OBDF} /$ calcium carbonate cleanup solutions of the $\mathrm{HCl}$, diesel, and a mixture of diesel, mutual solvent and glycol acid precursor (GAP). Regarding the returned permeability, the later solution outperformed the others. Xiao et al. (2015) proposed removing the ilmenite OBDF filter cake by soaking the filter cake for $2 \mathrm{~h}$ in a mutual solvent before soaking it for $4 \mathrm{~h}$ in $\mathrm{HCl}(5-15 \mathrm{wt} . \%)$.

In another study, Mohamed et al. (2019b) introduced a blend of mutual solvent ( 5 vol.\% EGMBE) and a biodegradable acid (50 vol.\%) to clean calcium carbonate-based filter cake. Their outcomes exhibited a complete regain in a sandstone core permeability and some stimulation in a limestone core.

From the studies shown above, it can be deduced that a combination of mutual solvent and acids can adequately remove calcium carbonate filter cakes. We recommend studying the effect of temperature on the removal efficiency of treatments that include a mutual solvent. Other mutual solvents rather than EGMBE can likewise be investigated to be used in filter cake cleanup solutions. 


\section{Acid plus surfactant}

Surfactants are chemicals that can lower the interfacial tension between different fluids and they have been used in the oil industry for various purposes such as emulsifiers, wettability alteration agents, dispersants, and defoamers (Salazar et al., 2011; Skalli et al., 2006; Yan et al., 1993; Yan and Sharma, 1989).

Binmoqbil et al. (2009) applied a solution consisting of formic acid precursor (15 vol.\%) and surfactant (2 vol.\%) in brine to dissolute oily calcium carbonate FC. The surfactant's purpose is to reverse the filter cake's wettability, allowing the acid and calcium carbonate reaction to take place. The studied treatment was able to completely retain the original permeability of the sandstone core sample.

Similarly, Al-Otaibi et al. (2010) reported a successful application of a mixture of brine, acetic acid (10 vol.\%), and surfactant (21 vol.\%) to remove the oil-based FC at both field and laboratory scale. Vickers et al. (2012) reported the ability of a similar treatment to that suggested by Al-Otaibi et al. (2010) to enhance the gas injectivity into a depleted sandstone reservoir. Zhou et al. (2018) presented a surfactant/oxidant system to remove OBDF filter cake in a single stage and reported that temperature and salinity considerably affect the performance of the surfactant in the cleanup process.

The surfactant performance in enhanced oil recovery was found to be considerably affected by $\mathrm{pH}$, surfactant concentration, salinity, and temperature. We recommend studying the effect of all those factors on the removal efficiency of acid-surfactant filter cake treatments.

\section{Mutual solvents, surfactant, and acid mixture}

Al-Kuait et al. (2012) presented field applications of a filter cake breaker that comprised of mutual solvent ( 2.5 to 5 vol.\%), water wetting surfactant (0.5-1 vol.\%), in addition to an organic acid precursor (OAP). The field applications demonstrated a significant improvement in the productivity of six out of eight wells that had been treated.

Mahmoud and Elkatatny (2019) presented several removal techniques for barite filter cake removal for OBDFs and WBDFs. The treatment of OBDF contained a chelating agent (0.6 M high pH EDTA), catalyst (10 wt.\% potassium carbonate), surfactant (0.1 wt.\%), and mutual solvent (15 vol.\% EGMBE) used in different proposed procedures. One method is to soak the filter cake into the mutual solvent for $4 \mathrm{~h}$ before soaking it into a mixture of $\mathrm{K}_{2} \mathrm{CO}_{3}$ and EDTA for another $24 \mathrm{~h}$. Another method is to combine the mutual solvent altogether in the solution and soak the filter cake for $24 \mathrm{~h}$ in a single stage. In the first scenario, the removal efficiency was $83 \%$, compared to $78 \%$ in the latter, but the single-stage method requires less time.

Siddig et al. (2020b) investigated a single-stage calcium carbonate removal solution that contains a mutual solvent (15 wt.\% EGMBE), nonionic surfactant (3 wt.\%), and acetic acid (15 wt.\%). They compared the removal efficiency with and without adding the mutual solvent and reported a significant increase when the mutual solvent was added. They additionally reported that the mutual solvent resulted in a decrease in solubility at high temperatures.

Adding both surfactant and mutual solvent to the acidic treatment for FC removal was reported to be more efficient compared to the surfactant/acid mixture. However, this means an increase in treatment cost that needs to be assessed compared to performance enhancement.

\section{Microemulsions}

Schulman and McRoberts (1946) introduced the microemulsions (ME), which were employed in the oil industry in the 1970s (Ahmed and Elraies, 2018; Healy and Reed, 1973). The microemulsion is a clear, stable, and homogenous fluid that consists of different immiscible fluids separated by a monolayer of surfactant (see Fig. 6) (Zana and Lang, 1987; Bohlen et al., 1992; Ezrahi et al., 1999). Adding alcohol to the surfactant will result in stabilized oil/water microemulsion (Quintero et al., 2005). The most common MEs are known as surfactant based microemulsions (SBME) and they are consist of water, oil, surfactant, and co-surfactant, and they have smaller droplets size (less than $100 \mathrm{~nm}$ ) compared to conventional emulsions (Quintero et al., 2007, 2005).

Another type of MEs is the surfactant-free microemulsions (SFME), which do not require the precence of the surfactant (Song et al., 2020). SFMEs have been introduced in 1977; however, they are not as common as SBMEs (Smith et al. 1977). SFME typically consists of water phase, oil
Fig. 6 Microemultions (Addagalla et al., 2016)

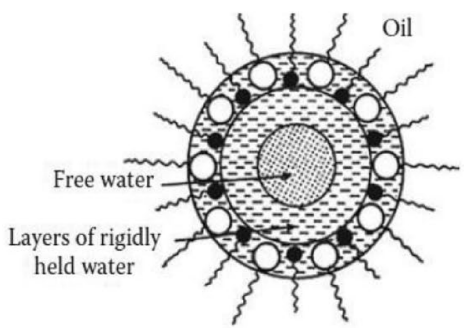

W/O Microemulsion

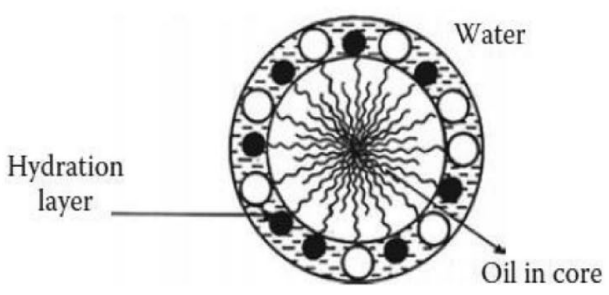

$\mathrm{O} / \mathrm{W}$ Microemulsion

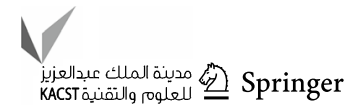




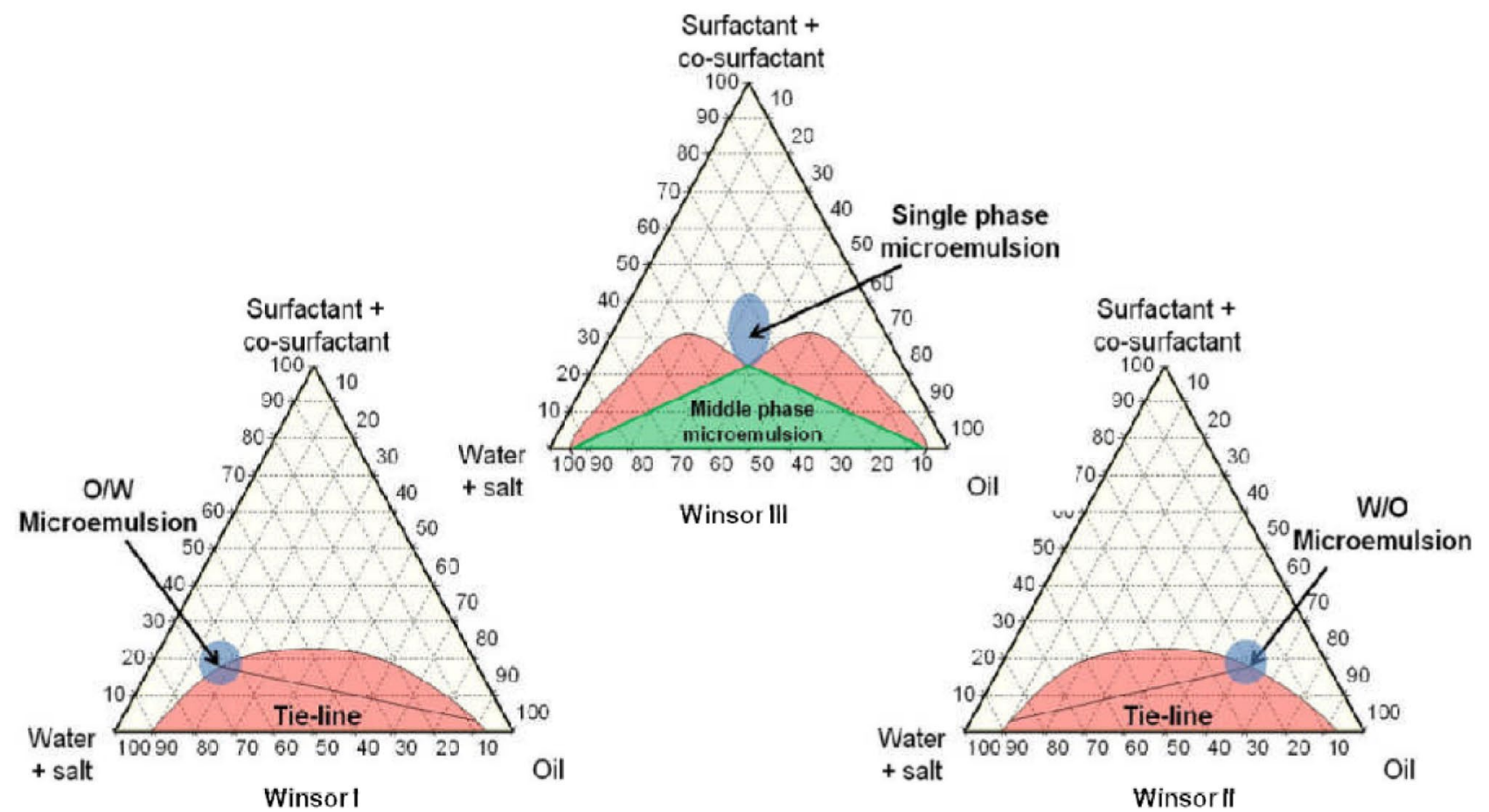

Fig. 7 Types of microemultions (Quintero et al., 2011)

phase and amphi-solvent, and the latter should be soluble in both of the two immiscible phases (Hou and $\mathrm{Xu}, 2016$ ). In contrast to SBMEs, fewer SFME system have been introduced in literature, eventhough both have almost similar properties (Liu et al., 2018).

MEs are infinitesimally heterogonous, homogeneous at the visible level, have high oil solubility, and extremely low interfacial tension (Salager, 1988). Figure 7 shows the phase behaviour and different types of microemulsions. These characteristics of the MEs facilitate solubilizing the oil, make the solid particles water-wet and consequently improve the OBDF filter cake clean up, especially when joined with acids (Brege et al., 2012; Darugar et al., 2012; Unsal et al., 2015).

Quintero et al. (2005) investigated a microemulsion-based treatment for calcium carbonate/barite filter cakes. The used a microemulsion comprised of water, surfactant, solvent, and co-surfactant added to brine, the microemulsion concentration range from 10 to $30 \%$ with acid concentration up to $7.5 \%$ in brine. They stated that soaking barite filter cake into the microemulsion, even without acid addition, made the filter cake more loose, porous, and changed the wettability of its solid particles. In their outcomes, combining acetic and hydrochloric acids to the microemulsion effectively removed the filter cake layer. For similar filter cakes, Quintero et al. (2007) presented a treatment in which formic acid is added to the microemulsion, and likewise, it was able to successfully break the filter cakes.
Lavoix et al. (2007) presented field applications on two wells in which a combination of acetic acid and ME was used to clean up filter cake residues that plugged the standalone screens. The filter cakes formed from OBDF were weighted with calcium carbonate. The treatment was able to reestablish the expected productivity index in each of the two wells. Another field application of alike treatment for standalone screens plugging by calcium carbonate filter cake was presented by Pietrangeli et al. (2014). The treatment solution consisted of brine (53-75 vol.\%), surfactant (15-20 vol.\%), acetic acid (10-15 vol.\%), co-surfactant (0-5 vol.\%), and a linker (0-2 vol.\%). Using this solution, the filter cake residues were effectively removed and the completion screens were unblocked.

Quintero et al. (2011) and Addagalla et al. (2016) reported that the performance of filter cake cleanup using ME relies on numerous factors such as temperature, salinity, oil type, type of acid/s, surfactant, and co-surfactant type. Accordingly, ME formulation should be customized for each field/ well application and several tests should be conducted to guarantee optimum performance (Brege et al., 2012). These tests include stability, fluids compatibility, and wettability alteration (Pietrangeli et al., 2014).

Recently, several authors presented a microemulsion pre-flush pill to clean the oil-based filter cake before pumping the cement and hence optimize the cementation integrity. Curbelo et al. (2019) and Araújo et al. (2020) presented biodegradable ME pre-flush, Curbelo et al. (2019) 
used vegetable oil plus the surfactant and the brine, while Araújo et al. (2020) investigated glycerol, freshwater and glycerol/water mixture as aqueous phases. Wanderley Neto et al. (2020) studied preflush that consisted of brine, surfactant, kerosene and n-butanol as co-surfactant. According to the authors, the compatibility between the preflush and the cement slurry is essential for a better cement bond. They also indicate the significance of wettability alteration on the quality of the cementation. The tested ME yielded a $100 \%$ areal clean-up efficiency and was compatible with the cement slurry.

da Silva et al. (2020a) presented an experimental investigation on the utilization of the produced formation water in microemulsion filter cake treatment that resulted in $100 \%$ removal efficiency. In addition to the produced water, the microemulsion is formed by kerosene, Butanol and Lauryl alcohol ethoxylates as surfactants. da Silva et al. (2020b) reported that the cosurfactant/surfactant ratio has a significant impact on the treatment in terms of wettability alteration and removal efficiency.

All the presented MEs applications are conventional SBME, and to the best of the authors' knowledge, no surfactant-free microemulsion treatment for filter cake removal has been presented in the literature. Therefore, studying the application of SFME in filter cake clean-up will be a valuable addition.

A summary of the different studies discussed the OBDF filter cake removal is presented in Tables 2 and 3. Table 2 presents a summary of the experimental procedures, while Table 3 summarizes the main findings on different treatments.

\section{Limitations and future perspectives}

Although a considerable number of publications have explored various aspects of filter cake removal, the review undertaken in this paper found that some areas in this topic require further investigation. The cleanup of filter cakes created by certain weighing materials, such as hematite and magnetite, for example, has not been adequately researched. It's also a good research area to investigate how salinity, temperature, and $\mathrm{pH}$ affect the overall efficiency of oil-based filter cake removal.

In most of the covered studies, the filter cakes were built in HPHT filter press for $30 \mathrm{~min}$ to $3 \mathrm{~h}$, and then, the filter cakes were exposed to the treatment. However, in reality, the filtration process can take much longer time, especially since the wells will be suspended before applying any treatments, therefore the study of time impact would be a good addition to this field.

The utilization of surfactant-free microemulsions in the treatment of oil-based filter cake is not studied presented in the literature. Investigating the application of SFME both technically and economically would be a worthwhile contribution.

\section{Lessons learnt}

In this paper, the treatment solutions of different weighting materials were summarized and a review of the different studies on OBDF's filter cake removal is presented. Based on the conducted review, the accompanying assertions are to summarize what has been canvassed in this paper:

- In general, oil-based FC removal is more sophisticated than water-based FC as the former requires a wettability alteration method in addition to the polymer breaker and the acid needed to dissolve the filter cake particles.

- Without wettability alteration, an oil film that encloses the solid particles restrains the reaction between the acid and the filter cake. This wettability adjustment is obtained by the addition of mutual solvents and/or surfactants to the treatment solution.

- The performance of these additives is affected by the temperature, salinity, $\mathrm{pH}$, and surfactant concentration.

- Including both the surfactant and mutual solvent in the treatment was found to be more efficient compared to the addition of surfactant only.

- Due to their low interfacial tension and high acid solubility, microemulsions were founded to be very effective in oil-based drilling fluid cleanup when added to an adequate acid. 
Table 2 Experimental procedure for the OBDF filter cake removal studies

\begin{tabular}{|c|c|c|}
\hline Author/s & Filter cake formation & Treatment perfomance test/s \\
\hline (Quintero et al., 2005) & $\begin{array}{l}\text { Porous medium: Ceramic disc, Berea sandstone core } \\
\text { Filteration duration: } 1 \text { to } 4 \mathrm{~h} \\
\text { Filtration on: permeability plug apparatus }\end{array}$ & $\begin{array}{l}\text { * Retained injection permeability tests using sandpack } \\
\text { and hassler permeameter } \\
\text { Treatment duration: } 2 \text { to } 16 \mathrm{~h}\end{array}$ \\
\hline (Davidson et al., 2006) & $\begin{array}{l}\text { Porous medium: Ceramic disc } \\
\text { Filteration duration: } 2 \mathrm{~h} \\
\text { Filtration on: dynamic displacement flow loop }\end{array}$ & $\begin{array}{l}\text { * Retained injection permeability tests using dynamic } \\
\text { displacement flow loop }\end{array}$ \\
\hline (Quintero et al., 2007) & $\begin{array}{l}\text { Porous medium: Ceramic disc } \\
\text { Filteration conditions: } 3 \mathrm{~h} \text { at } 1000 \mathrm{psi} \text { and } 150{ }^{\circ} \mathrm{F} \\
\text { Filtration on: HPHT filtration cell }\end{array}$ & $\begin{array}{l}\text { * Retained injection permeability tests using Sandpack } \\
\text { Permeameter } \\
\text { Treatment duration: } 3 \text { to } 20 \mathrm{~h}\end{array}$ \\
\hline (Ali et al., 2007) & $\begin{array}{l}\text { Porous medium: Ceramic disc and sandstone carbon- } \\
\text { ate core } \\
\text { Filteration duration: } 4 \mathrm{~h} \\
\text { Filtration on: static HPHT filtration cell }\end{array}$ & $\begin{array}{l}\text { *Retained permeability using a flow loop } \\
\text { Treatment duration: } 16 \mathrm{~h}\end{array}$ \\
\hline (Lavoix et al., 2007) & $\begin{array}{l}\text { Porous medium: Ceramic disc } \\
\text { Filteration conditions: } 3 \mathrm{~h} \text { at } 500 \text { psi and } 20{ }^{\circ} \mathrm{C} \\
\text { Filtration on: static HPHT filtration cell }\end{array}$ & $\begin{array}{l}\text { *Removal effeciency by weight } \\
\text { Treatment duration: overnight }\end{array}$ \\
\hline (Binmoqbil et al., 2009) & $\begin{array}{l}\text { Porous medium: Ceramic disc } \\
\text { Filteration conditions: } 3 \mathrm{~h} \text { at } 500 \mathrm{psi} \text { and } 188^{\circ} \mathrm{F} \\
\text { Filtration on: static HPHT filtration cell }\end{array}$ & $\begin{array}{l}\text { *Solubility } \\
\text { *Retained permeability using core flooding equipment } \\
\text { Treatment duration: } 24 \mathrm{~h}\end{array}$ \\
\hline (Al-Otaibi et al., 2010) & $\begin{array}{l}\text { Porous medium: Ceramic disc and sandstone core } \\
\text { Filteration conditions: } 3 \mathrm{~h} \text { at } 500 \mathrm{psi} \text { and } 188^{\circ} \mathrm{F} \\
\text { Filtration on: static HPHT filtration cell }\end{array}$ & $\begin{array}{l}\text { *Removal effeciency by weight } \\
\text { *Retained permeability using core flooding equipment } \\
\text { Treatment duration: } 24 \mathrm{~h}\end{array}$ \\
\hline (Al-Kuait et al., 2012) & $\begin{array}{l}\text { Porous medium: Ceramic disc } \\
\text { Filteration conditions: } 3 \mathrm{~h} \text { at } 500 \text { psi and } 150{ }^{\circ} \mathrm{F} \\
\text { Filtration on: static HPHT filtration cell }\end{array}$ & $\begin{array}{l}\text { *Retained permeability using HPHT cell } \\
\text { Treatment duration: } 24 \mathrm{~h}\end{array}$ \\
\hline (Pietrangeli et al., 2014) & $\begin{array}{l}\text { Porous medium: Ceramic disc } \\
\text { Filteration conditions: } 3 \mathrm{~h} \text { at } 360 \mathrm{psi} \text { and } 140{ }^{\circ} \mathrm{F} \\
\text { Filtration on: static HPHT filtration cell }\end{array}$ & $\begin{array}{l}\text { *Injection and production retained permeability } \\
\text { Treatment duration: } 68 \mathrm{~h}\end{array}$ \\
\hline (Xiao et al., 2015) & $\begin{array}{l}\text { Porous medium: sandstone core } \\
\text { Filteration conditions: } 3 \mathrm{~h} \text { at } 300 \text { psi and } 300{ }^{\circ} \mathrm{F} \\
\text { Filtration on: static HPHT filtration cell }\end{array}$ & $\begin{array}{l}\text { * Retained permeability using core flooding equipment } \\
\text { Treatment duration: } 6 \mathrm{~h}\end{array}$ \\
\hline (Addagalla et al., 2016) & $\begin{array}{l}\text { Porous medium: sandstone core } \\
\text { Filteration conditions: } 1 \mathrm{~h} \text { at } 315^{\circ} \mathrm{F} \\
\text { Filtration on: static HPHT filtration cell }\end{array}$ & *Filter cake wettability \\
\hline (Mahmoud and Elkatatny, 2019) & $\begin{array}{l}\text { Porous medium: Ceramic disc } \\
\text { Filteration conditions: } 1 / 2 \mathrm{~h} \text { at } 300 \mathrm{psi} \text { and } 300{ }^{\circ} \mathrm{F} \\
\text { Filtration on: static HPHT filtration cell }\end{array}$ & $\begin{array}{l}\text { *Compatibility } \\
\text { *Solubility } \\
\text { *removal effeciency by weight } \\
\text { Treatment duration: } 24 \mathrm{~h}\end{array}$ \\
\hline (Mohamed et al., 2019b) & $\begin{array}{l}\text { Porous medium: sandstone and limestone cores } \\
\text { Filteration conditions: } 1 / 2 \mathrm{~h} \text { at } 300 \mathrm{psi} \text { and } 212^{\circ} \mathrm{F} \\
\text { Filtration on: static HPHT filtration cell }\end{array}$ & $\begin{array}{l}\text { *Retained permeability using core flooding equipment } \\
\text { *Corrosion test } \\
\text { Treatment duration: } 24 \mathrm{~h}\end{array}$ \\
\hline (Siddig et al., 2020b) & $\begin{array}{l}\text { Porous medium: Ceramic disc and sandstone core } \\
\text { Filteration conditions: } 1 / 2 \mathrm{~h} \text { at } 300 \mathrm{psi} \text { and } 212^{\circ} \mathrm{F} \\
\text { Filtration on: static HPHT filtration cell }\end{array}$ & $\begin{array}{l}\text { *solubility } \\
\text { *removal effeciency by weight } \\
\text { *Retained permeability using core flooding equipment } \\
\text { *Corrosion test } \\
\text { Treatment duration: } 24 \mathrm{~h}\end{array}$ \\
\hline
\end{tabular}


Table 3 Summary of the OBDF filter cake removal studies

\begin{tabular}{|c|c|c|c|c|}
\hline Treatment & Acid used & Weighting material/s & Author/s & Remarks \\
\hline $\begin{array}{l}\text { Water or diesel + Mutual sol- } \\
\text { vent + acid }\end{array}$ & $\begin{array}{l}\text { FAP } \\
\text { GAP } \\
\text { green acid } \\
\text { HCL }\end{array}$ & Calcium carbonate & $\begin{array}{l}\text { (Davidson et al., 2006) } \\
\text { (Ali et al., 2007) } \\
\text { (Mohamed et al., 2019b) } \\
\text { (Xiao et al., 2015) }\end{array}$ & $\begin{array}{l}\text { Either soak a filter cake into } \\
\text { the mutual solvent for several } \\
\text { hours then add the acid solu- } \\
\text { tion or mix the mutual solvent } \\
\text { with the acid and soak in } \\
\text { one-step }\end{array}$ \\
\hline Brine + Surfactant + acid & $\begin{array}{l}\text { FAP } \\
\text { acetic acid }\end{array}$ & Calcium carbonate & $\begin{array}{l}\text { (Binmoqbil et al., 2009) } \\
\text { (Al-Otaibi et al., 2010; Vickers } \\
\text { et al., 2012) }\end{array}$ & $\begin{array}{l}\text { The surfactant reverses the } \\
\text { wettability that allows acids } \\
\text { reaction with filter cake's solid } \\
\text { particles }\end{array}$ \\
\hline $\begin{array}{l}\text { Water }+ \text { Mutual solvent }+ \text { Sur- } \\
\text { factant }+ \text { acid }\end{array}$ & $\begin{array}{l}\text { OAP } \\
\text { Acetic acid } \\
\text { EDTA and } \mathrm{K}_{2} \mathrm{CO}_{3}\end{array}$ & $\begin{array}{l}\text { Calcium carbonate } \\
\text { Barite }\end{array}$ & $\begin{array}{l}\text { (Al-Kuait et al., 2012) } \\
\text { (Siddig et al., 2020b) } \\
\text { (Mahmoud and Elkatatny, 2019) }\end{array}$ & $\begin{array}{l}\text { Adding mutual solvent to the } \\
\text { treatment solution improved } \\
\text { the removal performance } \\
\text { compared to when only the } \\
\text { surfactant was used }\end{array}$ \\
\hline Microemulsions + acid & $\begin{array}{l}\mathrm{HCl} / \text { acetic acid } \\
\text { formic acid } \\
\text { Acetic acid }\end{array}$ & $\begin{array}{l}\text { Barite, calcium car- } \\
\text { bonate or both } \\
\text { Calcium carbonate }\end{array}$ & $\begin{array}{l}\text { (Quintero et al., 2005) } \\
\text { (Quintero et al., 2007) } \\
\text { (Lavoix et al., 2007; Pietrangeli } \\
\text { et al., 2014) } \\
\text { (Addagalla et al., 2016) }\end{array}$ & $\begin{array}{l}\text { Soaking in microemulsions } \\
\text { reverse the wettability of the } \\
\text { FC } \\
\text { It results in a porous and loose } \\
\text { FC } \\
\text { When combining an adequate } \\
\text { acid to ME, the filter cake } \\
\text { could be removed efficiently }\end{array}$ \\
\hline
\end{tabular}

Funding This research received no external funding.

\section{Declarations}

Conflict of interest The authors declare no conflict of interest.

Open Access This article is licensed under a Creative Commons Attribution 4.0 International License, which permits use, sharing, adaptation, distribution and reproduction in any medium or format, as long as you give appropriate credit to the original author(s) and the source, provide a link to the Creative Commons licence, and indicate if changes were made. The images or other third party material in this article are included in the article's Creative Commons licence, unless indicated otherwise in a credit line to the material. If material is not included in the article's Creative Commons licence and your intended use is not permitted by statutory regulation or exceeds the permitted use, you will need to obtain permission directly from the copyright holder. To view a copy of this licence, visit http://creativecommons.org/licenses/by/4.0/.

\section{References}

Addagalla AKV, Kosandar BA, Lawal IG, Jadhav PB, Imran A, Al Saqer QR, Sherbeny WEl, Ansari A, Pino R, Gad-Alla AE, Olivaresantunez T (2016) Overcoming OBM filter cake damage using micro-emulsion remediation technology across a hightemperature formation. In: SPE International Conference and Exhibition on Formation Damage Control. Society of Petroleum Engineers. https://doi.org/10.2118/178942-MS

Ahmed S, Elraies KA (2018) Microemulsion in Enhanced Oil Recovery. In: Karakuş Selcan (ed) Science and Technology Behind Nanoemulsions. InTech. https://doi.org/10.5772/intechopen. 75778
Al Jaberi JB, Bageri BS, Barri A, Adebayo A, Patil S, Babu R, Rizwanullah S (2020) Insight into secondary posterior formation damage during barite filter cake removal in calcite formations. Int. Pet. Technol. Conf. https://doi.org/10.2523/IPTC-19611-MS

Al Moajil AM, Nasr-El-Din HA (2010) Reaction of hydrochloric acid with filter cake created by $\mathrm{Mn} 3 \mathrm{O} 4$ water-based drilling fluids. Trinidad Tobago Energy Resour Conf. https://doi.org/10.2118/ 133467-MS

Al Moajil AM, Nasr-El-Din HA (2013a) Removal of manganese tetraoxide filter cake using combination of $\mathrm{HCl}$ and organic acid. SPE Heavy Oil Conf. https://doi.org/10.2118/165551-MS

Al Moajil AM, Nasr-El-Din HA (2013b) Formation damage caused by improper Mn3O4-based filter-cake-cleanup treatments. J Can Pet Technol 52:64-74. https://doi.org/10.2118/144179-PA

Al Moajil AM, Nasr-El-Din HA, Al-Yami AS, Al-Aamri AD, AlAgil AK (2008) Removal of filter cake formed by manganese tetraoxide-based drilling fluids. SPE Int Symp Exhib Form Damage Control. https://doi.org/10.2118/112450-MS

Al-Anzi NA, Haider BYA, Gohain AK, Hussain I, Davidson E, Macmillan BH (2009) Carefully designed water-based drill-in fluid and filter cake removal system improves reservoir producibility and reduce well completion costs. In: 8th Eur. Form. Damage Conf. https://doi.org/10.2118/122327-MS

Al-Bagoury M (2014) Micronized ilmenite - a non-damaging nonsagging new weight material for drilling fluids. SPE Bergen One Day Semin. https://doi.org/10.2118/169182-MS

Al-bagoury M, Steele CD (2012) A New. IADC/SPE Drill. Conf. Exhib, Alternative Weight Material for Drilling Fluids. https:// doi.org/10.2118/151331-MS

Aldea C, Growcock F, Lee LJ, Friedheim J, Oort EV (2001) Prevention of dynamic sag in deepwater invert emulsion fluids, AADE 01-NC-HO-51. Houston, Texas, U.S.A.

Ali SA, Needham WJ, Luyster MR, Jones AGK, (2007) Novel chemistry eliminates post-cleanup of OBM filter cakes. In: European Formation Damage Conference. Society of Petroleum Engineers. https://doi.org/10.2118/106703-MS 
Alimuddin S, Yewlekar S, Raman CV, Bais SK, Anez M, Ezeigbo E, Kishore K, Patil B (2016) Strategically increasing completion efficiency by applying a customized filtercake breaker solution. SPE/IADC Middle East Drill Technol Conf Exhib. https://doi. org/10.2118/178209-MS

Al-Kuait AMS, Al-yateem KS, Olivares T, Zubail MA, El Bialy M, Ezell RG, Maghrabi S (2012) Improved producibility after delayed filter cake breaker treatment in the safaniya offshore field in Saudi Arabia. In: SPE Kuwait International Petroleum Conference and Exhibition. Society of Petroleum Engineers. https://doi.org/10.2118/163357-MS

Almutawa W, Ahmed A, Basfar S, Elkatatny S, Haidary S, Zitha P (2021) Investigation of magnetite-based invert emulsion mud at high pressure high temperature. Arab J Geosci 14:1913. https://doi.org/10.1007/s12517-021-08293-8

Al-Otaibi MB, Nasr-El-Din HA, Al Moajil AM (2006) In-situ acid system to clean up drill-in fluid damage in high temperature gas wells. IADC/SPE Asia Pacific Drill Technol Conf Exhib. https:// doi.org/10.2118/103846-MS

Al-Otaibi MB, Nasr-El-Din HA, Siddiqui MA (2004) Chemical Treatments to Enhance Productivity of Horizontal and Multilateral Wells: Lab Studies and Case Histories. SPE/DOE Symp. Improv. Oil Recover. https://doi.org/10.2118/89467-MS

Al-Otaibi MA, Binmoqbil KH, Rabba A, Abitrabi AN (2010) Singlestage chemical treatment for oil-based mud cake cleanup: lab studies and field case. In: SPE International Symposium and Exhibition on Formation Damage Control. Society of Petroleum Engineers. https://doi.org/10.2118/127795-MS

Al-Yami AS, Nasr-El-Din HA, (2007) An Innovative Manganese Tetroxide/KCl Water-Based Drill-in Fluid for HT/HP Wells. In: SPE Annu. Tech. Conf. Exhib. https://doi.org/10.2118/ 110638-MS

Araújo EA, Caminha TT, Paiva EM, Silva RR, Freitas JCO, Garnica AIC, Curbelo FDS (2020) Application of microemulsion systems in the formulation of biodegradable pre-flush fluid for primary cementing. Energies 13:4683. https://doi.org/10.3390/en131 84683

Argillier JF, Audibert A, Longeron D (1999) Performance evaluation and formation damage potential of new water-based drilling formulas. SPE Drill Complet 14:266-273. https://doi.org/10.2118/ 59484-PA

Ba geri BS, Al-Mutairi SH, Mahmoud MA (2013a) Different techniques for characterizing the filter cake. SPE Unconv Gas Conf Exhib. https://doi.org/10.2118/163960-MS

Ba geri BS, Al-Majed AA, Al-Mutairi SH, Ul-Hamid A, Sultan AS (2013b) Evaluation of filter cake mineralogy in extended reach and maximum reservoir contact wells in sandstone reservoirs. SPE/IADC Drill Conf. https://doi.org/10.2118/163519-MS

Ba geri BS, Mahmoud M, Elkatatny S, Patil S, Benaafi M, Mohamed A (2019a) Effect of drill cuttings mechanical properties on filter cake properties and mud-filtrate invasion. 53rd U.S. Rock Mech. Symp

Ba geri BS, Adebayo AR, Barri A, Jaberi JA, Patil S, Hussaini SR, Babu RS (2019b) Evaluation of secondary formation damage caused by the interaction of chelated barite with formation rocks during filter cake removal. J Petrol Sci Eng 183:106395. https://doi.org/10.1016/j.petrol.2019.106395

Ba geri BS, Mahmoud M, Al-Mutairi SH, Abdulraheem A (2015) Effect of sand content on the filter cake properties and removal during drilling maximum reservoir contact wells in sandstone reservoir. J Energy Resour Technol. https://doi.org/10.1115/1. 4032121

Ba geri BS, Mahmoud M, Al-Majed AA, Al-Mutairi SH, Abdulazeez A, Shawabkeh R (2017a) Water base barite filter cake removal using non-corrosive agents. SPE Middle East Oil Gas Show Conf. https://doi.org/10.2118/183653-MS
Ba geri BS, Mahmoud M, Abdulraheem A, Al-Mutairi SH, Elkatatny S, Shawabkeh RA (2017b) Single stage filter cake removal of barite weighted water based drilling fluid. J Pet Sci Eng 149:476484. https://doi.org/10.1016/j.petrol.2016.10.059

Basfar S, Elkatatny S (2020) Prevention of hematite settling using synthetic layered silicate while drilling high-pressure wells. Arab J Geosci 13:459. https://doi.org/10.1007/s12517-020-05516-2

Bern PA, Zamora M, Hemphill AT, Marshall D, Hughes B, Beardmore D, Omland TH, Morton EK (2010) Field Monitoring of WeightMaterial Sag. AADE-10-DF-HO-25. Houston, Texas, U.S.A.

Binmoqbil KH, Al-Otaibi MA, Al-Faifi MG, Al-Khudair WS, AlAamri AD (2009) Cleanup of oil-based mud filter cake using an in-situ acid generator system by a single-stage treatment. In: SPE Saudi Arabia Section Technical Symposium. Society of Petroleum Engineers. https://doi.org/10.2118/126065-MS

Bland RG, Mullen GA, Gonzalez YN, Harvey FE, Pless ML (2006) HPHT drilling fluid challenges. IADC/SPE Asia Pacific Drill Technol Conf Exhib. https://doi.org/10.2118/103731-MS

Blomberg NE, Melberg B (1984) Evaluation of ilmenite as weight material in drilling fluids. J Pet Technol 36:969-974. https://doi. org/10.2118/11085-PA

Bohlen DS, Vinson PK, Davis HT, Scriven LE, Xie M, Zhu X, Miller GW (1992) Generic Patterns in the Microstructure of Midrange Microemsulions. In: Friberg SE, Lindman B (eds) Organized Solutions. Surfactant Science Series, Marcel Dekker Inc, New York, NY, USA, p 145

Bourgoyne AT (1986) Applied drilling engineering

Boyou NV, Ismail I, Wan Sulaiman WR, Sharifi Haddad A, Husein N, Hui HT, Nadaraja K (2019) Experimental investigation of hole cleaning in directional drilling by using nano-enhanced waterbased drilling fluids. J Pet Sci Eng 176:220-231. https://doi.org/ 10.1016/j.petrol.2019.01.063

Brege JJ, El Sherbeny WIA, Quintero L, Jones TA (2012) Using microemulsion technology to remove oil-based mud in wellbore displacement and remediation applications. In: North Africa Technical Conference and Exhibition. Society of Petroleum Engineers. https://doi.org/10.2118/150237-MS

Burnett DB (1995) Using a physical wellbore model to study formation damage problems in well completions. SPE Drill Complet 10:61-65. https://doi.org/10.2118/27393-PA

Caenn R, Chillingar GV (1996) Drilling fluids: state of the art. J Pet Sci Eng 14:221-230. https://doi.org/10.1016/0920-4105(95)00051-8

Caenn R, Darley HCH, Gray GR (2017) Chapter 7 - The Filtration Properties of Drilling Fluids11A glossary of notation used in this chapter will be found immediately following this chapter's text. In: Caenn, R., Darley, H.C.H., Gray, G.R.B.T.-C. and P. of D. and C.F. (Seventh E. (Eds.) Gulf Professional Publishing, Boston, pp. 245-283. https://doi.org/10.1016/B978-0-12-804751-4.00007-9

Chellappah K, Tarleton ES, Wakeman R (2010) The porosity, permeability and restructuring of heterogeneous filter cakes. Chem Eng Technol 33:1283-1289. https://doi.org/10.1002/ceat.201000093

Civan F (1994) A multi-phase mud filtrate invasion and wellbore filter cake formation model. Int Pet Conf Exhib Mex. https://doi.org/ 10.2118/28709-MS

Collins N, Nzeadibe KI, Almond SW (2011) A biodegradable chelating agent designed to be an environmentally friendly filter-cake breaker. SPE Eur Heal Saf Environ Conf Oil Gas Explor Prod. https://doi.org/10.2118/140816-MS

Curbelo FDS, Caminha TT, Garnica AIC, Melo GNA, Araújo EA, Freitas JCO (2019) Microemulsion-based flushing fluid for effective removal of filter cake in wells cementation. Brazilian J Pet Gas 13:119-127. https://doi.org/10.5419/bjpg2019-0012

Da Silva DC, Araújo C, Freitas J, Rodrigues M, Wanderley Neto A (2020a) Formulation of new microemulsion systems containing produced water for removal of filter cake from olefin-based 
drilling fluid. J Petrol Sci Eng 193:107425. https://doi.org/10. 1016/j.petrol.2020.107425

da Silva VL, Ribeiro LS, de Oliveira Freitas JC, da Silva DNN, de Carvalho LS, Rodrigues MAF, de Wanderley Neto A, O., (2020b) Application of SDS surfactant microemulsion for removal of filter cake of oil-based drilling fluid: influence of cosurfactant. J Pet Explor Prod Technol 10:2845-2856. https://doi.org/10.1007/ s13202-020-00952-y

Darugar QA, Quintero L, Jones TA, Pietrangeli G (2012) Wellbore remediation using microemulsion technology to increase hydrocarbon productivity. SPE Saudi Arab Sect Tech Symp Exhib. https://doi.org/10.2118/160851-MS

Davidson E, McMillan DN, Martin F, Morton K, Lenz R (2006) Successful deployment of a new stimulation chemical, post horizontal open-hole gravel pack in wells drilled with both waterbased and oil-based drill-in-fluids. In: SPE/IADC Indian Drilling Technology Conference and Exhibition. Society of Petroleum Engineers. https://doi.org/10.2118/101964-MS

Davidson E, Mota L, Mosley N, Chimara G, Morrison AK, Archibald I (2012) New and effective filter cake removal optimizes water injectivity. In: SPE International Symposium and Exhibition on Formation Damage Control. Society of Petroleum Engineers. https://doi.org/10.2118/151683-MS

Davis E, Hodge R, Dick M, Mason S, Martens H (2004) Optimizing drill-in fluid \& completion cleanup processes for openhole horizontal gravelpacked completions in low temperature environments. SPE Int Symp Exhib Form Damage Control. https://doi. org/10.2118/86510-MS

Davison M, Jones M, Shuchart CE, Gerard C (2001) Oil-based muds for reservoir drilling: their performance and cleanup characteristics. SPE Drill Complet 16:127-134. https://doi.org/10.2118/ 72063-PA

Ding Y, Longeron D, Renard G, Audibert A (2004) Modeling of both near-wellbore damage and natural cleanup of horizontal wells drilled with water-based drilling fluids. SPE J 9:252-264. https:// doi.org/10.2118/88807-PA

Elkatatny S (2012) Evaluation of ilmenite as weighting material in water-based drilling fluids for HPHT applications. SPE Kuwait Int Pet Conf Exhib. https://doi.org/10.2118/163377-MS

Elkatatny S, Nasr-El-Din HA (2012) Properties of filter cake of waterbased drilling fluid under dynamic conditions using computer tomography. IADC/SPE Drill Conf Exhib. https://doi.org/10. 2118/151798-MS

Elkatatny S, Nasr-El-Din HA (2012) Removal efficiency of water-based drill-in fluid filter cake using polylactic acid. SPE Eur Annu Conf. https://doi.org/10.2118/154192-MS

Elkatatny S, Mahmoud MA, Nasr-El-Din HA (2011) A new approach to determine filter cake properties of water-based drilling fluids. SPE/DGS Saudi Arab Sect Tech Symp Exhib. https://doi.org/ 10.2118/149041-MS

Elkatatny S, Al Moajil AM, Nasr-El-Din HA (2012) Evaluation of a new environmentally friendly treatment to remove Mn3O4 filter cake. IADC/SPE Asia Pacific Drill Technol Conf Exhib. https://doi.org/10.2118/156451-MS

Elkatatny S, Mahmoud MA, Nasr-El-Din HA (2012b) Characterization of filter cake generated by water-based drilling fluids using CT scan. SPE Drill Complet 27:282-293. https://doi.org/10. 2118/144098-PA

Elkatatny S, Al Moajil AM, Nasr-El-Din HA (2013a) Filter cake cleanup using $\mathrm{HCl} / \mathrm{Glycolic}$ acid system. SPE Middle East Oil Gas Show Conf. https://doi.org/10.2118/164452-MS

Elkatatny S, Mahmoud M, Nasr-El-Din HA (2013b) Filter cake properties of water-based drilling fluids under static and dynamic conditions using computed tomography scan. J Energy Resour Technol. https://doi.org/10.1115/1.4023483
Elkatatny S, Xiao J, Nasr-El-Din HA, Al-Bagoury M (2013) Using hydrochloric acid to remove ilmenite water-based filter cake in HPHT applications. SPE Eur Form Damage Conf Exhib. https://doi.org/10.2118/165181-MS

Enright DP, Dye WM, Smith MF (1992) An environmentally safe water-based alternative to oil muds. SPE Drill Eng 7:15-19. https://doi.org/10.2118/21937-PA

Ezrahi S, Aserin A, Garti N (1999) Aggregation Behaviour in OnePhase (Winsor IV) Microemulsion systems. In: Kumar P, Mittal KL (eds) Handbook of Microemsulion Science and Technology. Marcel Dekker Inc, New York, USA, p 185

Fink, J.K., 2012. Chapter 1 - Drilling Muds. In: Fink, J.K.B.T.-P.E.G. to O.F.C. and F. (Eds.) Petroleum Engineer's Guide to Oil Field Chemicals and Fluids. Gulf Professional Publishing, Boston. pp. 1-59.

Fouda M, Amin R, Saleh H (2010) Preparation and characterization of nanosized titania prepared from beach black sands broad on the mediterranean sea coast in egypt via reaction with acids. Aust J Basic Appl Sci 4(10):4540-53

Frick TP, Economides MJ (1993) Horizontal well damage characterization and removal. SPE Prod Facil 8:15-22. https://doi. org/10.2118/21795-PA

Gordon C, Lewis S, Tonmukayakul P (2008) Rheological properties of cement spacer: mixture effects. Houston, Texas

Guo H, Vocken J, Opstal T, Dams R, Zitha PLJ (2012) Investigation of the mitigation of lost circulation in oil-based drilling fluids using additives. SPE Int Symp Exhib Form Damage Control. https://doi.org/10.2118/151751-MS

Haaland E, Pettersen G, Tuntland OB (1976) Testing Of iron oxides as weight materials for drilling muds.SPE-6218-MS.

Habib M, Biswas RK, Ali MR, Hasan AK (2006) Leaching of nontreated ilmenite by $\mathrm{HCl}-\mathrm{CH} 3 \mathrm{OH}-\mathrm{H} 2 \mathrm{O}$ mixture and its kinetics. Indian J Chem Technol, 13

Hall BE (1975) The effect of mutual solvents on adsorption in sandstone acidizing. J Pet Technol 27:1439-1442. https://doi.org/ 10.2118/5377-PA

Hamberlin CW, Thomas DC, Trbovich MG (1990) Combination of selected solvents and mutual solvents successful in removing hydrocarbon based formation damage. CIM/SPE Int Tech Meet. https://doi.org/10.2118/21572-MS

Hamzaoui B, Al Moajil AM, Caliskan S, Aldarweesh SS (2018) Filter Cake Buildup in Horizontal Wells: Characterization and Impact on Removal Operation. In: IADC/SPE Asia Pacific Drilling Technology Conference and Exhibition. Society of Petroleum Engineers. https://doi.org/10.2118/191075-MS

Han KN, Rubcumintara T, Fuerstenau MC (1987) Leaching behavior of ilmenite with sulfuric acid. Metall Trans B 18:325-330. https://doi.org/10.1007/BF02656150

Hanssen JE, Jiang P, Pedersen HH, Jørgensen JF (1999) New enzyme process for downhole cleanup of reservoir drilling fluid filtercake. SPE Int Symp Oilf Chem. https://doi.org/10.2118/ 50709-MS

Healy RN, Reed RL (1973) Physicochemical aspects of microemulsion flooding. Fall Meet Soc Pet Eng AIME. https://doi.org/10. 2118/4583-MS

Hossain M, Al-Majed AA (2015) Drilling Fluids, In: Fundamentals of Sustainable Drilling Engineering, Wiley Online Books. Scrivener Publishing LLC., pp. 73-139.

Hou W, Xu J (2016) Surfactant-free microemulsions. Curr Opin Colloid Interface Sci 25:67-74. https://doi.org/10.1016/j.cocis.2016. 06.013

Howard SK (1995) Formate brines for drilling and completion: state of the art. SPE Annu Tech Conf Exhib. https://doi.org/10.2118/ 30498-MS

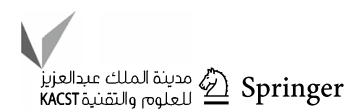


Huang S, Guo X, Duan W, Cheng X, Zhang X, Li Z (2019) Degradation of high molecular weight polyacrylamide by alkali-activated persulfate: reactivity and potential application in filter cake removal before cementing. J Pet Sci Eng 174:70-79. https://doi. org/10.1016/j.petrol.2018.10.108

Ikram R, Mohamed Jan B, Vejpravova J, Choudhary MI, Zaman Chowdhury Z (2020) Recent advances of graphene-derived nanocomposites in water-based drilling fluids. Nanomaterials 10(10):2004. https://doi.org/10.3390/nano10102004

Ikram R, Mohamed Jan B, Sidek K, G., (2021) Utilization of ecofriendly waste generated nanomaterials inwater-based drilling fluids. State of the Art Rev Mater 14:4171. https://doi.org/10. 3390/ma14154171

Imqam A, Elue H, Muhammed FA, Bai B (2014) Hydrochloric acid applications to improve particle gel conformance control treatment. SPE Niger Annu Int Conf Exhib. https://doi.org/10.2118/ 172352-MS

Iscan AG, Civan F, Kok MV (2007) Alteration of permeability by drilling fluid invasion and flow reversal. J Pet Sci Eng 58:227-244. https://doi.org/10.1016/j.petrol.2007.01.002

Jensen B, Paulsen JE, Saasen A, Prebensen OI, Balzer H (2004) Application of Water Based Drilling Fluid - Total Fluid Management. IADC/SPE Drill Conf. https://doi.org/10.2118/87103-MS

Jiao D, Sharma MM (1992) Formation damage due to static and dynamic filtration of water-based muds. SPE Form Damage Control Symp. https://doi.org/10.2118/23823-MS

Kabir A, Gamwo IK (2011) Filter cake formation on the vertical well at high temperature and high pressure: computational fluid dynamics modeling and simulations. J Petroleum Gas Eng 2(7):146164. https://doi.org/10.5897/JPGE11.026

Karakul H (2018) Effects of drilling fluids on the strength properties of clay-bearing rocks. Arab J Geosci 11:450. https://doi.org/10. 1007/s12517-018-3816-8

Khodja M, Canselier JP, Bergaya F, Fourar K, Khodja M, Cohaut N, Benmounah A (2010) Shale problems and water-based drilling fluid optimisation in the Hassi Messaoud Algerian oil field. Appl Clay Sci 49:383-393. https://doi.org/10.1016/j.clay.2010.06.008

Lakatos I, Lakatos-Szabo J, Kosztin B (2002) Comparative study of different barite dissolvers: technical and economic aspects. Int Symp Exhib Form Damage Control. https://doi.org/10.2118/ 73719-MS

Lavoix F, Jones TA, Quintero L, Le Prat X, Leschi P, Aubry E (2007) First application of novel microemulsion technology for sand control remediation operations - a successful case history from the rosa field, a deepwater development project in Angola. Eur Form Damage Conf. https://doi.org/10.2118/107341-MS

Leschi P, Demarthon G, Davidson E, Clinch D (2006) Delayed-Release Acid System for Cleanup of Al Khalij Horizontal Openhole Drains, In: SPE International Symposium and Exhibition on Formation Damage Control. Society of Petroleum Engineers. https://doi.org/10.2118/98164-MS

Li D, He W (2015) Journey into filter cakes: a microstructural study. Int Pet Technol Conf. https://doi.org/10.2523/IPTC-18246-MS

Liu H, Papangelakis VG, Alam MS, Singh G (2003) Solubility of Hematite in $\mathrm{H} 2 \mathrm{SO} 4$ Solutions at $230-270{ }^{\circ} \mathrm{C}$. Can Metall Q 42:199-207. https://doi.org/10.1179/cmq.2003.42.2.199

Liu Y, Xu J, Deng H, Song J, Hou W (2018) A surfactant-free microemulsion composed of isopentyl acetate, $\mathrm{n}$-propanol, and water. RSC Adv 8:1371-1377. https://doi.org/10.1039/C7RA12594A

Mahmoud M, Elkatatny S (2017) Towards a Complete Removal of Barite Weighted Water and Oil Based-Drilling Fluids in Single Stage. In: SPE Annual Technical Conference and Exhibition. Society of Petroleum Engineers. https://doi.org/10.2118/ 187122-MS

Mahmoud MANE-D, Elkatatny S (2019) Removal of barite-scale and barite-weighted water- or oil-based-drilling-fluid residue in a single stage. SPE Drill Complet 34:016-026. https://doi.org/10. 2118/187122-PA

Matsumoto K, Taniguchi S, Kikuchi A (1994) Leaching rate of hematite in nitric acid solutions in agitated vessel. J Japan Inst Met 58:291-296. https://doi.org/10.2320/jinstmet1952.58.3_291

Mohamed A, Basfar S, Elkatatny S, Al-Majed A (2019a) Prevention of barite sag in oil-based drilling fluids using a mixture of barite and ilmenite as weighting material. Sustainability 11:5617. https:// doi.org/10.3390/su11205617

Mohamed A, Elkatatny S, Basfar S, (2019b) One-Stage Calcium Carbonate Oil-Based Filter Cake Removal Using a New Biodegradable Acid System. In: SPE Kuwait Oil \& Gas Show and Conference. Society of Petroleum Engineers. https://doi.org/10.2118/ 198045-MS

Nasr-El-Din HA, Al Moajil AM (2007) Evaluation of in-situ generated acids for filter cake clean up. Eur Form Damage Conf. https:// doi.org/10.2118/107537-MS

Nasr-El-Din HA, Al-Otaibi MGH, Al-Qahtani AM, McKay ID (2005) Lab studies and field application of in-situ generated acid to remove filter cake in gas wells. SPE Annu Tech Conf Exhib. https://doi.org/10.2118/96965-MS

Navarro-mascarella R, Luyster M (2011) High density Breaker Fluids and Methods of Use Thereof. US Patent patent No. 61870

Parlar M, Tibbles RJ, Chang FF, Fu D, Morris L, Davison M, Vinod PS, Wierenga A (1998) Laboratory development of a novel simultaneous cake-cleanup and gravel-packing system for long highly-deviated or horizontal open-hole completions. Eur Pet Conf. https://doi.org/10.2118/50651-MS

Patel A, Stamatakis S, Young S, Friedheim J (2007) Advances in inhibitive water-based drilling fluids - can they replace oil-based muds? Int Symp Oilf Chem. https://doi.org/10.2118/106476-MS

Pehrson EW, Keiser HD (1945) Minerals yearbook 1945

Pietrangeli G, Quintero L, Jones TA, Benaissa S, Menezes CA, Aubry E, Poitrenaud H, Furgier JN (2014) Overcoming wellbore cleanup challenges in deepwater wells in West Africa, In: SPE International Symposium and Exhibition on Formation Damage Control. Society of Petroleum Engineers. https://doi.org/10. 2118/168215-MS

Quintero L, Jones TA, Pietrangeli G (2011) Phase boundaries of microemulsion systems help to increase productivity. SPE Eur Form Damage Conf. https://doi.org/10.2118/144209-MS

Quintero L, Jones TA, Clark DE (2005) One step acid removal of invert emulsion, In: SPE European Formation Damage Conference. Society of Petroleum Engineers. https://doi.org/10.2118/ 94604-MS

Quintero L, Jones TA, Clark D, Twynam AJ (2007) NAF filter cake removal using microemulsion technology. In: European Formation Damage Conference. Society of Petroleum Engineers. https://doi.org/10.2118/107499-MS

Rabia H (2001) chapter 7. Well Engineering and Construction. Entrac Petroleum, London, United Kingdom, pp 197-234

Rae P, Di Lullo G, bte Ahmad, A., (2001) Towards environmentallyfriendly additives for well completion and stimulation operations. SPE Asia Pacific Oil Gas Conf Exhib. https://doi.org/10.2118/ 68651-MS

Rafati R, Smith SR, Sharifi Haddad A, Novara R, Hamidi H (2018) Effect of nanoparticles on the modifications of drilling fluids properties: a review of recent advances. J Pet Sci Eng 161:61-76. https://doi.org/10.1016/j.petrol.2017.11.067

Rostami A, Nasr-El-Din HA (2010) Optimization of a solid-acid precursor for self-destructing filter cake. SPE East Reg Meet. https:// doi.org/10.2118/139087-MS

Rostami A, Nasr-El-Din HA (2010) New technology for filter cake removal. SPE Russ Oil Gas Conf Exhib. https://doi.org/10.2118/ 136400-MS 
Saasen A, Hoset H, Rostad EJ, Fjogstad A, Aunan O, Westgård E, Norkyn PI (2001) Application of ilmenite as weight material in water based and oil based drilling fluids. SPE Annu Tech Conf Exhib. https://doi.org/10.2118/71401-MS

Salager JL (1988) Phase Transformation and Emulsion Inversion on the Basis of Catastrophe Theory. In: Becher P (ed) Encyclopedia of Emulsion Technology: Basic Theory Mesurement and Applications. Marcel Dekker Inc, New York, USA, p 79

Salazar JM, Torres-Verdin C, Wang GL (2011) Effects of surfactantemulsified oil-based mud on borehole resistivity measurements. SPE J 16:608-624. https://doi.org/10.2118/109946-PA

Sarwar MU, Cawiezel KE, Nasr-El-Din HA (2011) Gel degradation studies of oxidative and enzyme breakers to optimize breaker type and concentration for effective break profiles at low and medium temperature ranges. SPE Hydraul Fract Technol Conf. https://doi.org/10.2118/140520-MS

Sayindla S, Lund B, Ytrehus JD, Saasen A (2017) Hole-cleaning performance comparison of oil-based and water-based drilling fluids. J Pet Sci Eng 159:49-57. https://doi.org/10.1016/j.petrol. 2017.08.069

Schulman JH, McRoberts TS (1946) On the structure of transparent water and oil dispersions (solubilised oils). Trans Faraday Soc 42:B165. https://doi.org/10.1039/tf946420b165

Sharma MM, Zhang R, Chenevert ME, Ji L, Guo Q, Friedheim J (2012) A new family of nanoparticle based drilling fluids. SPE Annu Tech Conf Exhib. https://doi.org/10.2118/160045-MS

Siddig O, Mahmoud AA, Elkatatny S (2020a) A review of different approaches for water-based drilling fluid filter cake removal. J Pet Sci Eng 192:107346. https://doi.org/10.1016/j.petrol.2020. 107346

Siddig O, Al-Afnan S, Elkatatny S, Bahgat M (2020b) Novel cake washer for removing oil-based calcium carbonate filter cake in horizontal wells. Sustainability 12:3427. https://doi.org/10.3390/ su12083427

Siddiqui MAA, Al-Anazi HA, Al-Ansari AA, Bataweel MA, Hembling DE (2006) Evaluation of acid precursor-enzyme system for filter cake removal by a single stage treatment. SPE Eur Annu Conf Exhib. https://doi.org/10.2118/99799-MS

Sidhu P, Gilkes R, CORNELL, R., POSNER, A., QUIRK, J., (1981) Dissolution of iron oxides and oxyhydroxides in hydrochloric and perchloric acids. Clays Clay Miner 29:269-276. https://doi. org/10.1346/CCMN.1981.0290404

Skalli L, Buckley JS, Zhang Y, Morrow NR (2006) Surface and core wetting effects of surfactants in oil-based drilling fluids. J Pet Sci Eng 52:253-260. https://doi.org/10.1016/j.petrol.2006.03.012

Smith GD, Donelan CE, Barden RE (1977) Oil-continuous microemulsions composed of hexane, water, and 2-propanol. J Colloid Interface Sci 60:488-496. https://doi.org/10.1016/0021-9797(77) 90313-7

Smith SR, Rafati R, Sharifi Haddad A, Cooper A, Hamidi H (2018) Application of aluminium oxide nanoparticles to enhance rheological and filtration properties of water based muds at HPHT conditions. Colloids Surfaces A Physicochem Eng Asp 537:361371. https://doi.org/10.1016/j.colsurfa.2017.10.050

Song M, Liu W, Wang Q, Wang J, Chai J (2020) A surfactant-free microemulsion containing diethyl malonate, ethanol, and water: microstructure, micropolarity and solubilizations. J Ind Eng Chem 83:81-89. https://doi.org/10.1016/j.jiec.2019.11.016

Svendsen O, Toften JK, Marshall DS, Hermansson CL (1995) Use of a novel drill-in/completion fluid based on potassium formate brine on the first open hole completion in the gullfaks field. SPE/IADC Drill Conf. https://doi.org/10.2118/29409-MS

Tehrani A, Cliffe A, Hodder MH, Young S, Lee J, Stark J, Seale S (2014) Alternative drilling fluid weighting agents: a comprehensive study on ilmenite and hematite. IADC/SPE Drill Conf Exhib. https://doi.org/10.2118/167937-MS
Thomas B, Sharma MM (1998) Distribution of mud induced damage around horizontal wellbores. SPE Form Damage Control Conf. https://doi.org/10.2118/39468-MS

Tibbles RJM, Parlar M, Chang FF, Fu D, Davison M, Morris L, Wierenga A, Vinod PS (2003) Fluid and Techniques for Hydrocarbon Well Completion. Patent No. 6140277.

Tovar J, Rodriguez Z, Quiroga F, Greaves R, Melendez H, Arocha J, Bland R, Hebert M (1999) ORIMATITA®. Lat Am Caribb Pet Eng Conf, An Improved Hematite for Drilling Fluids. https://doi. org/10.2118/53939-MS

Unsal E, Broens M, Buijse M, Boersma D, Makurat A, Armstrong RT (2015) Visualization of microemulsion phase. SPE Asia Pacific Enhanc Oil Recover Conf. https://doi.org/10.2118/174651-MS

van Dyk JP, Vegter NM, Pistorius PC (2002) Kinetics of ilmenite dissolution in hydrochloric acid. Hydrometallurgy 65:31-36. https:// doi.org/10.1016/S0304-386X(02)00063-4

Vickers S, Bruce S, Hutton A, Nunzi P (2012) Protect and then inject: optimized well fluids successfully drill depleted reservoirs to store gas. SPE Drill Complet 27:113-117. https://doi.org/10. 2118/144798-PA

Walker CO (1983) Alternative weighting material. J Pet Technol 35:2158-2164. https://doi.org/10.2118/11116-PA

Wanderley Neto AO, da Silva VL, Rodrigues DV, Ribeiro LS, Nunes da Silva DN, de Oliveira Freitas JC (2020) A novel oil-in-water microemulsion as a cementation flushing fluid for removing nonaqueous filter cake. J Petrol Sci Eng. https://doi.org/10.1016/j. petrol.2019.106536

Wang C, Meng R, Xiao F, Wang R (2016) Use of nanoemulsion for effective removal of both oil-based drilling fluid and filter cake. J Nat Gas Sci Eng 36:328-338. https://doi.org/10.1016/j.jngse. 2016.10.035

Weast RC (1979) Handbook Of Chemistry And Physics, 60th, Editi. CRC Press Inc, Florida, USA

Xiao J, Nasr-El-Din HA, Al-Bagoury M (2015) Removal of Ilmenite Oil-based Filter Cake under HP/HT Conditions Using Hydrochloric Acid. In: SPE North Africa Technical Conference and Exhibition. Society of Petroleum Engineers. https://doi.org/10. 2118/175728-MS

Yan J, Sharma MM (1989) Wettability alteration and restoration for cores contaminated with oil-based muds. J Pet Sci Eng 2:63-76. https://doi.org/10.1016/0920-4105(89)90051-X

Yan J-N, Monezes JL, Sharma MM (1993) Wettability Alteration Caused by Oil-Based Muds and Mud Components. SPE Drill Complet 8:35-44. https://doi.org/10.2118/18162-PA

Yao R, Jiang G, Li W, Deng T, Zhang H (2014) Effect of water-based drilling fluid components on filter cake structure. Powder Technol 262:51-61. https://doi.org/10.1016/j.powtec.2014.04.060

Zain ZM, Sharma MM (1999) Cleanup of wall-building filter cakes. SPE Annu Tech Conf Exhib. https://doi.org/10.2118/56635-MS

Zamora M, Bell RL (2004) Improved Wellsite Test for Monitoring Barite Sag, AADE-04-DF-HO-19. Houston, TX, USA

Zana R, Lang J (1987) Dynamic of Microemulsions. In: Friderg SE, Bothorel P (eds) Micremulsion: Structure and Dynamics. CRC Press Inc, FL, USA, p 153

Zhang X, You L, Kang Y, Zhang C, Zhang G, Tan Q (2020) Formation damage control of saline-lacustrine fractured tight oil reservoir during well drilling. Arab J Geosci 13:1087. https://doi.org/10. 1007/s12517-020-06099-8

Zhou J, Nasr-El-Din HA, Socci D, Holcomb J (2018) A Cost-Effective Application of New Surfactant/Oxidant System to Enhance the Removal Efficiency of Oil-Based Mud Filter Cake, In: SPE Western Regional Meeting. Society of Petroleum Engineers. https:// doi.org/10.2118/190115-MS

Publisher's Note Springer Nature remains neutral with regard to jurisdictional claims in published maps and institutional affiliations.

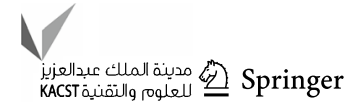

